\title{
Assessment of the Contribution of Road Runoffs to Surface Water Pollution in the New Juaben Municipality, Ghana
}

\author{
Louis Korbla Doamekpor' ${ }^{1}$, Richmond Darko', Raphael Kwaku Klake ${ }^{1}$, \\ Victus Bobonkey Samlafo², Lord Hunuor Bobobee², Cornelius Kwame Akpabli', \\ Vincent Kodzo Nartey ${ }^{1}$ \\ ${ }^{1}$ Department of Chemistry, School of Physical and Mathematical Sciences, University of Ghana, Accra, Ghana \\ ${ }^{2}$ Department of Chemistry Education, University of Education Winneba, Winneba, Ghana \\ Email: Ikdoamekpor@gmail.com
}

Received 8 December 2015; accepted 26 January 2016; published 29 January 2016

Copyright (C) 2016 by authors and Scientific Research Publishing Inc.

This work is licensed under the Creative Commons Attribution International License (CC BY).

http://creativecommons.org/licenses/by/4.0/

(c) (i) Open Access

\section{Abstract}

Road runoffs were sampled from five highways and five urban roads located in the New Juaben Municipality during the late storm events in the month of November 2014 and the early storm events in January 2015. A variety of water quality parameters such as, $\mathrm{pH}$, temperature, turbidity, electrical conductivity (EC), total suspended solids (TSS), total dissolved solids (TDS), aqueous concentrations of Chloride $\left(\mathrm{Cl}^{-}\right)$, Phosphate $\left(\mathrm{PO}_{4}^{3-}\right)$, Nitrate $\left(\mathrm{NO}_{3}^{-}\right)$and Sulphate $\left(\mathrm{SO}_{4}^{2-}\right)$ ions as well as the total concentrations of some selected heavy metals $(\mathrm{Fe}, \mathrm{Cu}, \mathrm{Zn}, \mathrm{Pb}, \mathrm{Cd}, \mathrm{Ni}$ and $\mathrm{Cr}$ ) were analysed for both periods. Although the results for the studied parameters, particularly the heavy metals varied for both sampling periods, the general trend indicated an increase in accumulation from November 2014 to January 2015. This was attributed to vehicular deposition as well as other natural and anthropogenic depositions on the road surfaces during the antecedent dry weather period between the two sampling months. The highest increase in pollutant loadings was associated with the heavy metals and some physico-chemical parameters such as TSS, TDS, EC and turbidity. Generally, EC, TDS, TSS and turbidity were above the permissible limits of the Environmental Protection Agency (EPA) of Ghana for both sampling periods. However, almost all the mean concentrations of heavy metals recorded for both road runoffs and the control samples were within the permissible limits of the Ghana EPA with some few exceptions.

\section{Keywords}

Early Storm Event, Late Storm Event, Road Runoff, Highways, Urban Roads, New Juaben 


\section{Municipality}

\section{Introduction}

Environmental pollution has always been a problem in Ghana, despite efforts to reduce pollutant loading from point and nonpoint sources. Examples of point sources are factories, power plants, sewage treatment plants, underground coal mines and oil wells [1]. Nonpoint sources of pollution are diffuse and therefore harder to control. In urban areas, anthropogenic activities generate atmospheric emissions that mostly consist of submicron-sized particles and aerosols and therefore play a major role in contributing to the pollution of water bodies [2]. Rapid population growth, urbanization and large-scale development are potential factors in the pollution of road runoffs from urban roads and highways within a municipality and it also becomes a serious problem, particularly in the heavily populated areas, where natural exchange of air is restricted by a compact settlement [3]-[5]. The protection of the water resource is getting more complicated, due to the recognition of polluted runoff, as a major problem [6]. This diffuse form of pollution which is fast becoming one of the nation's leading threats to water quality, is derived from contaminants washed off the surface of roads by rain water, and carried either directly or indirectly into waterways or groundwater [7]. The increasing number of over-aged vehicles in conjunction with heavy traffic in a municipality has also contributed to the pollution of the environment with heavy metals and has become a major concern because of their toxicity and threat to human life and the environment. Second-hand (home use) spare parts (tyres, brake lining, clutch plate lining, bearing and bushing, moving engine parts, etc.), which are commonly used by vehicle owners, wear out easily leaving contaminants on the surface of the roads and are carried from the road surfaces in road runoffs during storm events, and either infiltrate into the soils within the immediate environment or may end up in various water sources [4] [8] [9]. Incomplete combustion of fuel as a result of bad catalytic converters in vehicles are responsible for the emission of aerosol gases and soot particles (black colloidal substance consisting wholly of amorphous carbon) into the atmosphere subsequently undergo dry or wet deposition which in turn pollutes the environment [10] [11]. Pollution of traditional surface water resources no doubt restricts the diversity of water supply options for the New Juaben Municipality [12]. Storm water runoff problems are nothing new to the municipal assemblies. However, the principal concern about runoff has always been safety, with the focus on direction and draining water off the paved surfaces as quickly and efficiently as possible to avoid flooding. Once off the road and out of sight, storm water has been largely out of mind forgetting that these runoffs are moving into surrounding water bodies which serve as a direct source of drinking water for some communities within or outside the municipality [2] [13] [14]. The variability from one location to another is caused by differences in land-use, seasonal influences, atmospheric deposition, maintenance, road drainage designs, and vehicles as well as other automobiles indicates the need for local data. It is therefore imperative to assess road runoffs in the municipality, to be able to gather information regarding their contribution to the pollution of surface water.

Till now, very few studies have been conducted to assess the contribution of road runoffs, which is fast gaining grounds as one of the most important sources of surface water pollution in Ghana. The absence of any system to manage or treat road runoffs to a harmless level that meets the acceptable water quality standards is therefore likely to cause environmental and economic risks. It is in this light that the study aims at assessing the extent to which road runoff is a significant contributor to surface water pollution in the New Juaben municipality.

\section{Materials and Methods}

\subsection{Study Area}

The New Juaben Municipal Assembly, Figure 1(a) and Figure $1(\mathrm{~b}),\left(6^{\circ} 06^{\prime} \mathrm{N}, 0^{\circ} 16^{\prime} \mathrm{W}\right)$ is one of the four municipalities established under the Local Government Act 462 of 1988. The municipality was granted its present status by the Legislative Instrument (LI) 1426 of 1988. The New Juaben Municipal Assembly covers a land area of about 110 square kilometres with a road network totaling $72 \mathrm{~km}$. It shares boundaries to the north-east with East Akim Municipality, to the south-east with Akuapem-North District, Yilo Krobo District to the east and Suhum Kraboa Coaltar District to the west. In essence, the area of the land stretches from Suhyen to Okroase to 
L. K. Doamekpor et al.

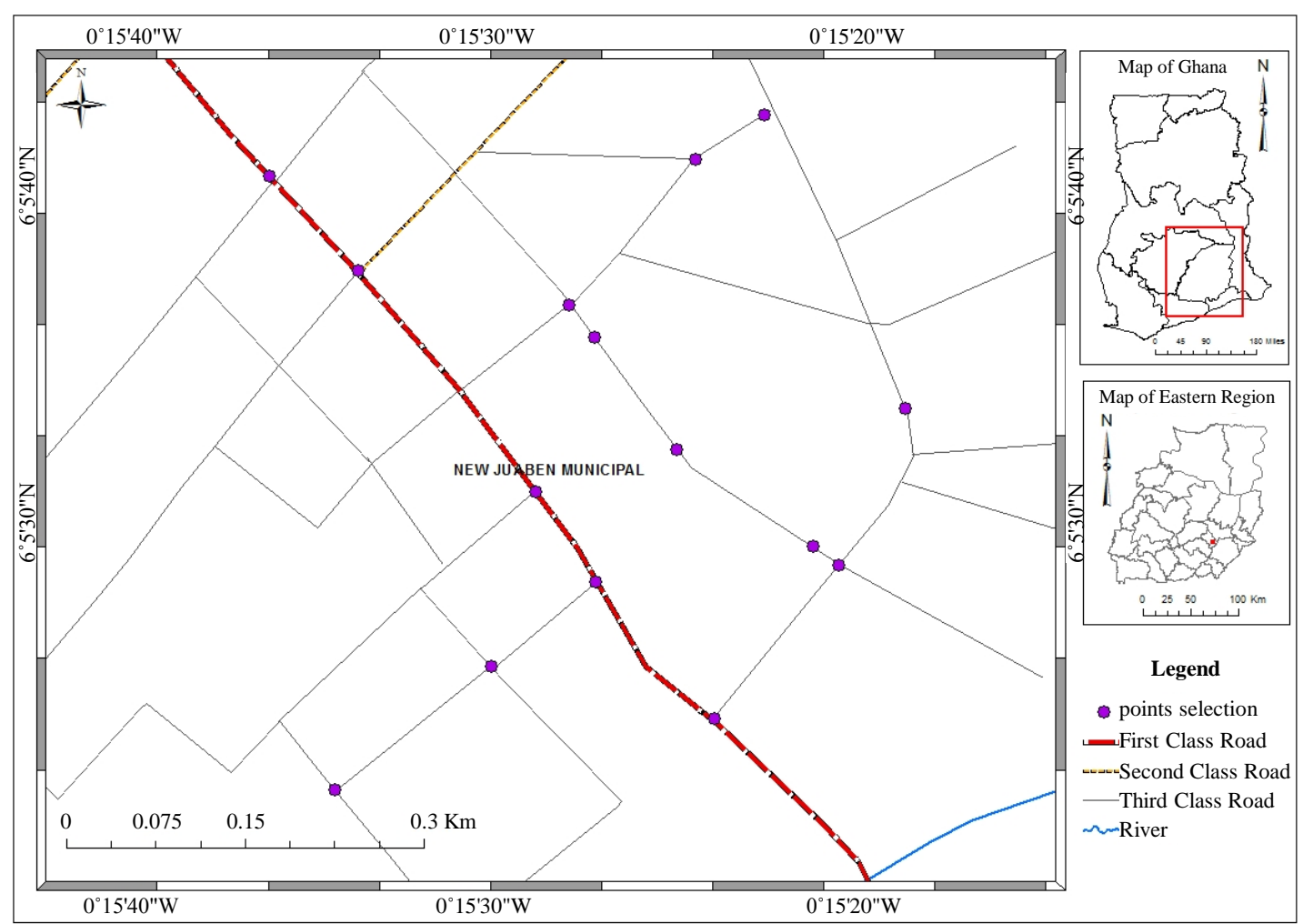

(a)

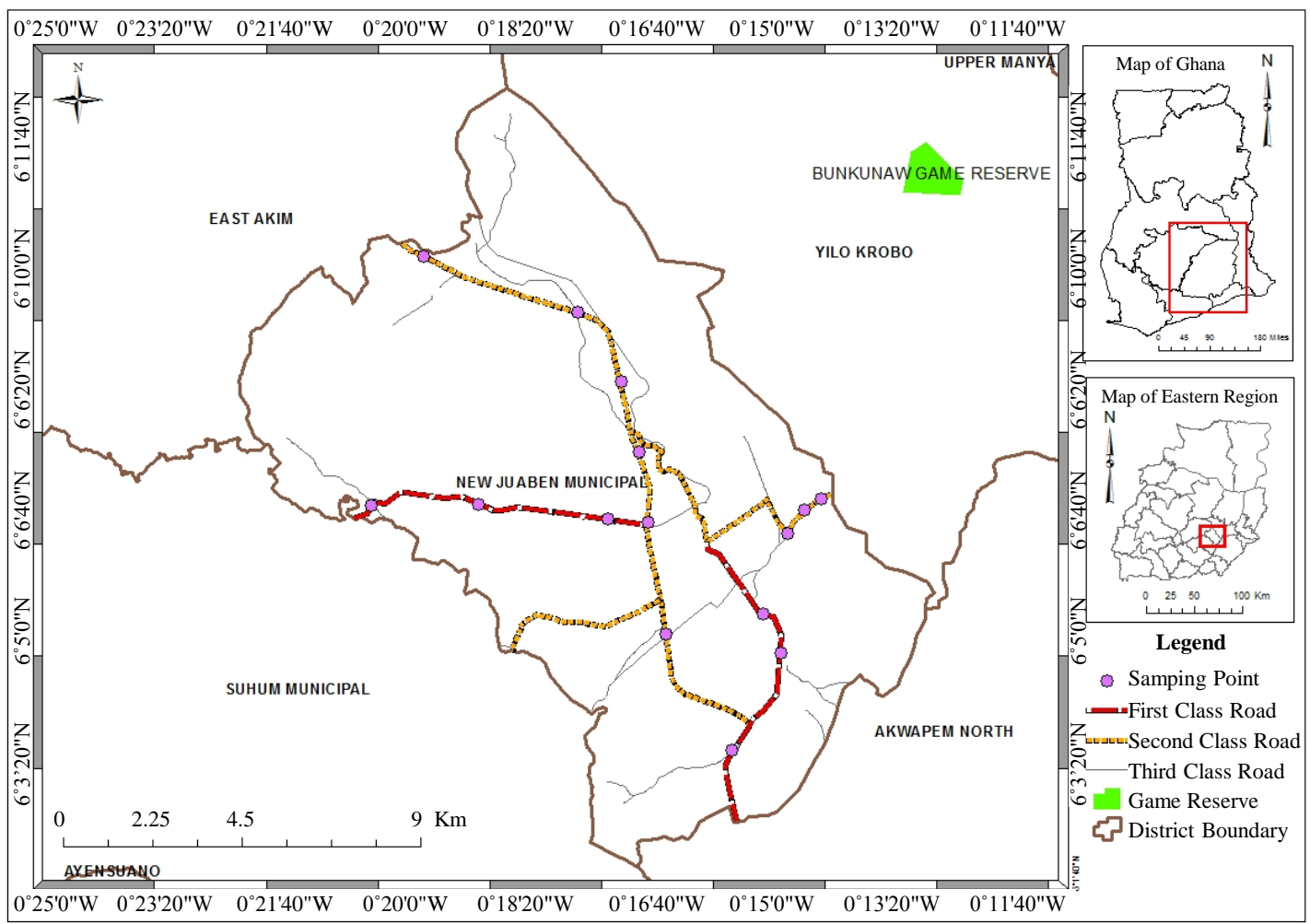

(b)

Figure 1. (a): Map showing the sampling points on the Urban Road sites, (b): Map showing the sampling points on the Highway sites. 
Aboabo and to Akwadum [15]. Almost all the existing settlements in the municipality are reached by improved condition of tarred roads and feeder roads [12] [16]. The Municipality falls within the semi-deciduous rain forest climatic zone with the rainy season occurring in two modes of between $1580 \mathrm{~mm}$ and $1780 \mathrm{~mm}$ reaching its maximum during the two peak periods of April/July and September/November. The dry season is relatively short and is experienced between November and February. Mean monthly temperature ranges from as high as $30^{\circ} \mathrm{C}$ in the dry season but declines to about $26^{\circ} \mathrm{C}$ in the rainy season [17]. The 2010 Population and Housing Census put the estimated population of the municipality at 183,727 for the year 2010. Koforidua being the regional and municipal capital of the New Juaben Municipality recorded an estimated population of 130,810 in the 2010 population census which is about $71 \%$ of the entire population in the municipality. Koforidua as the centre of most administrative and commercial activities performs most functions such as social, economic and political activities resulting in the influx of population in the municipality [16] [18].

\subsection{Sample Collection}

Runoff samples were collected for two different months, Table 1, based on weather reports, predicted quantity of rain, laboratory workload, and proximity to the weekend. Road runoff samples were collected from the edge of the road/highway within the first 10 to 20 minutes of downfall when runoff has just begun, depending on the intensity of the rain. This was done on ten selected routes within the New Juaben Municipality. The sampling sites, Table 2, Figure 1(a) and Figure 1(b), include Market Avenue (MAV), Old Library Road (OLR), Nana Kwaku Boateng Street (NKB), Total 2 road (TOT 2), Adu Sakodie Street (ADSK), Koforidua-Jumapo Highway (KJU), Koforidua-Akwadum Highway (KAKD), Koforidua-Nkurakan Highway (KNK), Kasajan Highway (KASJ) and Adweso Highway (ADWE).

The sampling locations differed in daily traffic flow and surrounding land use. Accessibility for runoff sampling was also considered during site selection. The first set of samples was collected in November 2014 and the second set of samples was collected in January 2015. The choice of these months was to capture the effect of the antecedent dry period brought about by the dry (harmattan) season on the quality of road runoff in the study area. Two rain water samples (one from the urban area and the other from the highway area), were collected directly about 3 meters above the ground level during the storm events and were treated as control samples.

\subsection{Sample Preparation and Analysis}

The road runoff samples were collected directly into acid pre-cleaned $1.5 \mathrm{~L}$ polyethylene bottles and labelled with the appropriate sample site numbers and placed in an ice chest at a temperature of $4^{\circ} \mathrm{C}$. Necessary care was taken to avoid contamination of the samples in the course of transportation to the laboratory, storage and analysis.

Table 1. Sampling locations and dates of sampling of road runoffs.

\begin{tabular}{|c|c|c|c|c|}
\hline \multirow[b]{2}{*}{ Sample location } & \multirow[b]{2}{*}{ Sample code } & \multirow[b]{2}{*}{$\begin{array}{l}\text { 24-Hour traffic volume } \\
\text { (vehs/day) }\end{array}$} & \multicolumn{2}{|c|}{ Sampling dates } \\
\hline & & & Late rainfall & Early rainfall \\
\hline Koforidua-Akwadum Highway & KAKD & 11,361 & 4th November 2014 & 20th January 2015 \\
\hline Koforidua-Jumapo Highway & KJU & 10,160 & 4th November 2014 & 20th January 2015 \\
\hline Koforidua-Nkurakan Highway & KNK & 16,778 & 6th November 2014 & 26th January 2015 \\
\hline Kasajan Highway & KASJ & 8213 & 6th November 2014 & 21st January 2015 \\
\hline Adweso Highway & ADWE & 18,088 & 10th November 2014 & 26th January 2015 \\
\hline Nana Kwaku Boateng Street & NKB & 6852 & 10th November 2014 & 26th January 2015 \\
\hline Market Avenue & MAV & 2815 & 10th November 2014 & 26th January 2015 \\
\hline Old Library Road & OLR & 3309 & 10th November 2014 & 26th January 2015 \\
\hline Total 2 Road & TOT 2 & 19,409 & 10th November 2014 & 26th January 2015 \\
\hline Adu Sakodie Street & ADSK & 5362 & 10th November 2014 & 26th January 2015 \\
\hline
\end{tabular}


Table 2. Sample codes and location of sampling points.

\begin{tabular}{|c|c|c|c|c|c|c|c|}
\hline \multirow{2}{*}{ Sampling sites } & \multirow{2}{*}{ Sample codes } & \multicolumn{2}{|c|}{ Sampling point 1} & \multicolumn{2}{|c|}{ Sampling point 2} & \multicolumn{2}{|c|}{ Sampling point 3} \\
\hline & & Longitude & Latitude & Longitude & Latitude & Longitude & Latitude \\
\hline Market Avenue & MAV & $\mathrm{W} 0.2577^{\circ}$ & N $6.0932^{\circ}$ & $\mathrm{W} 0.2571^{\circ}$ & $\mathrm{N} 6.0925^{\circ}$ & $\mathrm{W} 0.2558^{\circ}$ & $\mathrm{N} 6.0913^{\circ}$ \\
\hline Old Lib. Road & OLR & $\mathrm{W} 0.2577^{\circ}$ & N $6.0911^{\circ}$ & W $0.2584^{\circ}$ & N $6.0905^{\circ}$ & W $0.2595^{\circ}$ & $\mathrm{N} 6.0897^{\circ}$ \\
\hline Nana Kwaku Boateng & NKB & $\mathrm{W} 0.2616^{\circ}$ & $\mathrm{N} 0.0837^{\circ}$ & W $0.2559^{\circ}$ & N $6.0910^{\circ}$ & W $0.2551^{\circ}$ & N $6.0921^{\circ}$ \\
\hline Total 2 Street & TOT 2 & $\mathrm{~W} 0.2600^{\circ}$ & N $6.0942^{\circ}$ & $\mathrm{W} 0.2593^{\circ}$ & N $6.0936^{\circ}$ & W $0.2582^{\circ}$ & N $6.0916^{\circ}$ \\
\hline Adu Sakodie Street & ADSK & W $0.2564^{\circ}$ & $\mathrm{N} 6.0947^{\circ}$ & $\mathrm{W} 0.2570^{\circ}$ & $\mathrm{N} 6.0945^{\circ}$ & $\mathrm{W} 0.2578^{\circ}$ & $\mathrm{N} 6.0933^{\circ}$ \\
\hline Koforidua-Jumapo & KJU & W $0.2862^{\circ}$ & N $6.1400^{\circ}$ & W $0.2960^{\circ}$ & N 6.1556 & $\mathrm{W} 0.3311^{\circ}$ & N $6.1685^{\circ}$ \\
\hline Koforidua-Akwadum & KAKD & W $0.3432^{\circ}$ & N $6.1117^{\circ}$ & W $0.3188^{\circ}$ & N 6.1119 & W $0.2892^{\circ}$ & N $6.1085^{\circ}$ \\
\hline Koforidua-Nkurakan & KNK & W $0.2420^{\circ}$ & N $6.1130^{\circ}$ & $\mathrm{W} 0.2460^{\circ}$ & N $6.1100^{\circ}$ & W $0.2483^{\circ}$ & N $6.1052^{\circ}$ \\
\hline Kasajan Highway & KASJ & W $0.2760^{\circ}$ & N $6.0823^{\circ}$ & W $0.2802^{\circ}$ & N 6.1078 & W $0.2821^{\circ}$ & N 6.1239 \\
\hline Adweso Highway & ADWE & $\mathrm{W} 0.2610^{\circ}$ & N $6.0559^{\circ}$ & $\mathrm{W} 0.2500^{\circ}$ & $\mathrm{N} 6.0781^{\circ}$ & $\mathrm{W} 0.2539^{\circ}$ & N $6.0869^{\circ}$ \\
\hline
\end{tabular}

All pH measurements were done using a digital pH meter (AB15 pH meter, Fisher Scientific, Hampton, NH). The instrument was calibrated for each set of measurements with standard buffer solutions. However, the temperatures of the road runoff samples were determined in the field using a thermometer. The TDS and the Electrical Conductivity were measured using a digital conductivity meter (Hanna instruments), calibrated with 0.01 $\mathrm{M} \mathrm{KCl}$ solution. The argentometric method was used to determine the chloride concentration in the runoff samples while the absorptometric method was applied in the determination of the turbidity using the cybercan IR TB 100 turbidimeter. The sulphate ion concentrations were determined by the Automated Methylthymol Blue Method. However, ascorbic acid method was applied in the determination of phosphate.

The laboratory analysis of the runoff samples were done using VARIAN AAS 240FS-Atomic Absorption Spectrometer to measure the concentration of the selected heavy metals such as cadmium, copper, chromium, zinc, iron, nickel and lead. The runoff water samples were digested using concentrated nitric acid $\mathrm{HNO}_{3}$ and concentration of the selected heavy metals were determined. The essence of the digestion before analysis was to reduce the interference of organic matter and convert the metal to a form that can be analyzed by AAS.

Interpretation of the overall heavy metal concentrations in the sampled road runoff was drawn by using Mean, Standard Deviation, Skewness and Kurtosis. The results of the analyses were compared to the permissible limits set by the Environmental Protection Agency of Ghana for effluent discharge, as contaminated effluent affects man and his environment.

\section{Results and Discussion}

\section{Temperature}

The study revealed that mean temperature ranged from a minimum of $25^{\circ} \mathrm{C}$ at sites KAKD and KASJ to a maximum of $27.3^{\circ} \mathrm{C}$ at site MAV in November 2014, Table 3(a) and Table 3(c). January 2015, Table 3(b) and Table 3(d), also recorded a minimum temperature value of $26.1^{\circ} \mathrm{C}$ at site $\mathrm{KJU}$ and a maximum value of $28.6^{\circ} \mathrm{C}$ at site MAV. The control samples recorded values of $24.10^{\circ} \mathrm{C}$ and $25.63^{\circ} \mathrm{C}$ in the respective months, Table 3(c) and Table 3(d). The overall mean temperature for all the sites recorded a value of $25.70^{\circ} \mathrm{C} \pm 0.78^{\circ} \mathrm{C}$ and $27.10^{\circ} \mathrm{C} \pm 0.80^{\circ} \mathrm{C}$ for November 2014 and January 2015 respectively. The higher values of temperature recorded for road runoffs sampled in January 2015 as compared to those recorded for road runoffs sampled in November 2014 might be as a result of the hot weather due to the dry season. Since rainfall is cold and cools the surfaces it wets, road runoffs can absorb significant heat as it flows over the road surfaces. The control samples which recorded low values of temperature as compared to the sampled road runoffs gave a clear indication that, the storm water got heated as they flowed over the road surfaces [5].

Electrical Conductivity (EC)

The study revealed that mean EC ranged from a minimum value of $804.40 \mu \mathrm{S} / \mathrm{cm}$ at site KAKD to 2850.10 $\mu \mathrm{S} / \mathrm{cm}$ at site NKB in November 2014, Table 3(a). January 2015 also gave a minimum conductivity value of 
Table 3. (a): Mean values of physico-chemical parameters of sampled road runoffs in November 2014; (b): Mean values of physico-chemical parameters of sampled road runoffs in January 2015; (c): Statistical summary of physico-chemical parameters of sampled runoffs from all the sites in November 2014; (d): Statistical summary of physico-chemical parameters of sampled runoffs from all the sites in January 2015.

(a)

\begin{tabular}{cccccccccccc}
\hline & \multicolumn{1}{c}{ Urban roads } \\
\hline PARAMETER & MAV & OLR & NKB & TOT 2 & ADSK & KJU & KAKD & KNK & KASJ & ADWE \\
\hline pH & 6.60 & 6.71 & 6.57 & 6.67 & 6.63 & 7.33 & 7.12 & 6.78 & 6.88 & 6.80 \\
Temperature $\left({ }^{\circ} \mathrm{C}\right)$ & 27.30 & 25.60 & 26.50 & 26.10 & 26.10 & 25.10 & 25.00 & 25.10 & 25.00 & 25.10 \\
EC $(\mu \mathrm{S} / \mathrm{cm})$ & 2620.30 & 1580.67 & 2850.10 & 2340.30 & 2532.78 & 1204.50 & 804.40 & 1325.40 & 1000.12 & 1459.00 \\
TSS $(\mathrm{mg} / \mathrm{L})$ & 98.15 & 64.95 & 104.43 & 71.67 & 69.88 & 56.07 & 38.33 & 66.33 & 47.10 & 68.67 \\
TDS $(\mathrm{mg} / \mathrm{L})$ & 1654.80 & 1074.23 & 2010.93 & 1740.10 & 1520.40 & 818.67 & 594.31 & 776.10 & 648.40 & 940.20 \\
Turbidity $(\mathrm{NTU})$ & 108.22 & 78.33 & 156.40 & 104.35 & 98.10 & 92.73 & 46.15 & 81.17 & 59.40 & 72.78 \\
Chloride $(\mathrm{mg} / \mathrm{L})$ & 33.40 & 26.33 & 38.48 & 31.08 & 29.78 & 15.40 & 17.93 & 21.47 & 20.43 & 22.60 \\
Sulphate $(\mathrm{mg} / \mathrm{L})$ & 49.73 & 36.67 & 58.31 & 34.52 & 54.17 & 17.88 & 14.48 & 24.67 & 18.67 & 21.08 \\
Phosphate $(\mathrm{mg} / \mathrm{L})$ & 2.31 & 0.41 & 3.09 & 0.04 & 1.44 & 10.78 & 8.67 & 6.67 & 5.67 & 6.48 \\
Nitrate $(\mathrm{mg} / \mathrm{L})$ & 18.88 & 11.21 & 22.33 & 14.67 & 17.40 & 4.40 & 10.28 & 12.06 & 9.12 & 13.73 \\
\hline
\end{tabular}

(b)

\begin{tabular}{cccccccccccc}
\hline & \multicolumn{9}{c}{ Urban roads } \\
\hline PARAMETER & MAV & OLR & NKB & TOT 2 & ADSK & KJU & KAKD & KNK & KASJ & ADWE \\
\hline pH & 5.03 & 5.66 & 5.47 & 5.52 & 5.57 & 6.02 & 5.78 & 5.67 & 5.77 & 5.59 \\
Temperature $\left({ }^{\circ} \mathrm{C}\right)$ & 28.60 & 26.70 & 28.10 & 27.60 & 27.40 & 26.10 & 26.40 & 26.90 & 26.20 & 27.10 \\
EC $(\mu \mathrm{S} / \mathrm{cm})$ & 7196.13 & 3466.15 & 6820.98 & 6740.88 & 6510.02 & 1749.05 & 2496.78 & 2854.23 & 1978.17 & 4310.09 \\
TSS $(\mathrm{mg} / \mathrm{L})$ & 212.67 & 180.31 & 242.21 & 205.35 & 327.35 & 158.52 & 137.43 & 179.33 & 162.95 & 201.02 \\
TDS $(\mathrm{mg} / \mathrm{L})$ & 4792.73 & 2241.99 & 4570.08 & 4488.02 & 4542.40 & 1435.65 & 1670.65 & 1864.21 & 1370.13 & 2870.78 \\
Turbidity (NTU) & 279.67 & 242.05 & 299.48 & 261.67 & 397.96 & 224.06 & 152.08 & 190.13 & 201.67 & 243.47 \\
Chloride (mg/L) & 96.88 & 58.88 & 104.13 & 82.43 & 77.67 & 43.08 & 46.21 & 53.41 & 56.47 & 72.40 \\
Sulphate (mg/L) & 172.15 & 72.92 & 148.48 & 112.33 & 120.07 & 51.67 & 58.10 & 68.40 & 69.73 & 94.67 \\
Phosphate (mg/L) & 11.75 & 13.67 & 3.93 & 2.78 & 16.33 & 18.67 & 37.40 & 28.10 & 11.93 & 5.67 \\
Nitrate $(\mathrm{mg} / \mathrm{L})$ & 87.33 & 37.33 & 64.12 & 76.40 & 42.67 & 25.92 & 27.52 & 35.67 & 30.67 & 58.40 \\
\hline
\end{tabular}

(c)

\begin{tabular}{|c|c|c|c|c|c|c|c|}
\hline & Minimum & Maximum & Mean & Std. Dev. & Kurtosis & Skewness & Control sample \\
\hline $\mathrm{pH}$ & 6.57 & 7.33 & 6.81 & 0.24 & 1.14 & 1.31 & 6.51 \\
\hline Temperature $\left({ }^{\circ} \mathrm{C}\right)$ & 25.00 & 27.30 & 25.70 & 0.78 & 0.11 & 0.96 & 24.10 \\
\hline $\mathrm{EC}(\mu \mathrm{S} / \mathrm{cm})$ & 804.40 & 2850.10 & 1771.76 & 743.25 & -1.69 & 0.27 & 576.78 \\
\hline TSS (mg/L) & 38.33 & 104.43 & 68.56 & 20.33 & 0.11 & 0.53 & 3.51 \\
\hline TDS (mg/L) & 594.31 & 2010.93 & 1177.76 & 509.18 & -1.45 & 0.45 & 381.40 \\
\hline Turbidity (NTU) & 46.15 & 156.40 & 89.76 & 30.53 & 1.80 & 0.91 & 9.16 \\
\hline Chloride (mg/L) & 15.40 & 38.48 & 25.69 & 7.38 & -0.85 & 0.33 & 13.10 \\
\hline Sulphate (mg/L) & 14.48 & 58.31 & 33.02 & 16.23 & -1.43 & 0.49 & 17.90 \\
\hline Phosphate (mg/L) & 0.04 & 10.78 & 4.56 & 3.64 & -1.05 & 0.34 & 0.04 \\
\hline Nitrate (mg/L) & 4.40 & 22.33 & 13.41 & 5.19 & 0.01 & 0.08 & 2.10 \\
\hline
\end{tabular}


(d)

\begin{tabular}{cccccccc}
\hline & Minimum & Maximum & Mean & Std. Dev. & Kurtosis & Skewness & Control Sample \\
\hline pH & 5.03 & 6.02 & 5.61 & 0.25 & 2.77 & -0.95 & 5.57 \\
Temperature $\left({ }^{\circ} \mathrm{C}\right)$ & 26.10 & 28.60 & 27.10 & 0.80 & -0.04 & 0.78 & 25.63 \\
EC $(\mu \mathrm{S} / \mathrm{cm})$ & 1749.05 & 7196.13 & 4412.25 & 2195.82 & -2.01 & 0.16 & 1837.78 \\
TSS $(\mathrm{mg} / \mathrm{L})$ & 137.43 & 327.35 & 200.71 & 53.76 & 3.02 & 1.52 & 11.34 \\
TDS $(\mathrm{mg} / \mathrm{L})$ & 1370.13 & 4792.73 & 2984.66 & 1453.81 & -2.12 & 0.23 & 1219.67 \\
Turbidity $(\mathrm{NTU})$ & 152.08 & 397.96 & 249.22 & 68.02 & 1.81 & 0.97 & 25.54 \\
Chloride $(\mathrm{mg} / \mathrm{L})$ & 43.08 & 104.13 & 69.16 & 21.01 & -1.02 & 0.45 & 28.67 \\
Sulphate $(\mathrm{mg} / \mathrm{L})$ & 51.67 & 172.15 & 96.85 & 40.52 & -0.49 & 0.78 & 35.64 \\
Phosphate $(\mathrm{mg} / \mathrm{L})$ & 2.78 & 37.40 & 15.02 & 10.90 & 0.69 & 1.01 & 0.65 \\
Nitrate $(\mathrm{mg} / \mathrm{L})$ & 25.92 & 87.33 & 48.60 & 21.65 & -0.83 & 0.73 & 16.30 \\
\hline
\end{tabular}

$1749.05 \mu \mathrm{S} / \mathrm{cm}$ at site KJU and a maximum value of $7196.13 \mu \mathrm{S} / \mathrm{cm}$ at site MAV, Table 3(b). The control samples also recorded values of $576.78 \mu \mathrm{S} / \mathrm{cm}$ and $1837.78 \mu \mathrm{S} / \mathrm{cm}$ for the respective months, Table 3(c) and Table 3(d). From the table of results, the overall mean conductivity for all the sites in November 2014 recorded a value of $1771.76 \pm 743.36 \mu \mathrm{S} / \mathrm{cm}$ and January 2015 gave a value of $4412.25 \pm 2195.82 \mu \mathrm{S} / \mathrm{cm}$. The variations in conductivity may be due to the contributions from wet and dry depositions of soluble inorganic ions such as chloride, nitrate, sulphate, and phosphate onto the road surfaces during the antecedent dry weather period before the January 2015 sampling was conducted. These ions dissolve during a precipitation event and are eventually washed off into runoffs, thus increasing the dissolved ion concentration which is responsible for the high level of electrical conductivity. However, a strong correlation was observed between the measured EC with the pH and the temperature for both sampling periods [19].

\section{Total Dissolved Solids (TDS)}

Analysis of water samples of the study area showed that the mean TDS ranged from a minimum of 594.31 $\mathrm{mg} / \mathrm{L}$ at site KAKD to a maximum of $2010.93 \mathrm{mg} / \mathrm{L}$ at site NKB in November 2014, Table 3(a). January 2015 recorded a minimum TDS value of $1370.13 \mathrm{mg} / \mathrm{L}$ at site KASJ and a maximum value of $4792.73 \mathrm{mg} / \mathrm{L}$ at site MAV, Table 3(b). The control samples also recorded values of $381.40 \mathrm{mg} / \mathrm{L}$ and $1219.67 \mathrm{mg} / \mathrm{L}$ in the respective months, Table 3(c) and Table 3(d). The overall mean TDS for all the sites in November 2014 was $1177.76 \pm$ $509.18 \mathrm{mg} / \mathrm{L}$ and that for all the sites in January 2015 was $2984.66 \pm 1453.808 \mathrm{mg} / \mathrm{L}$. High TDS values recorded for both sampling periods implies that the road runoffs contain dissolved minerals which were washed off the surface of the road and this is evidenced by the strong correlation coefficient $\left(\mathrm{R}^{2}=0.958\right.$ and $\left.\mathrm{R}^{2}=0.995\right)$ observed between TDS and EC for the November 2014 and the January 2015 sampling periods respectively, Figure 2(a) and Figure 2(b).

\section{Total Suspended Solids (TSS)}

The study revealed that the mean TSS ranged from a minimum of $38.33 \mathrm{mg} / \mathrm{L}$ at site KAKD to a maximum of $104.43 \mathrm{mg} / \mathrm{L}$ at site NKB in November 2014, Table 3(a). January 2015 also recorded a minimum TSS value of $137.43 \mathrm{mg} / \mathrm{L}$ at site KAKD and a maximum value of $327.35 \mathrm{mg} / \mathrm{L}$ at site ADSK, Table 3(b). The control samples gave values of $3.51 \mathrm{mg} / \mathrm{L}$ and $11.34 \mathrm{mg} / \mathrm{L}$ for the respective months. The overall mean TSS for all the sites in November 2014 was $68.56 \pm 20.33 \mathrm{mg} / \mathrm{L}$ and that for all the sites in January 2015 was $200.71 \pm 53.75 \mathrm{mg} / \mathrm{L}$. High TSS values recorded for both sampling periods might be due to indirect deposition of solids onto the road surface by vehicles that carry solid materials from roads which are not tarred and construction sites. In general, all urban roads recorded very high values as compared to those recorded by the highway sites which are evidence that vehicle turbulence can actually reduce the amount of solids that has collected on highway surfaces between storm events [20] [21]. ADWE however recorded the highest TSS value for the highway sites in both sampling periods because it is near the urban area of the municipality and this confirms the finding of Martina Winkler [22] who found higher amounts of atmospheric dust fall on highways near urban areas. Besides, ADWE carries a heavy volume of traffic, Table 1. 


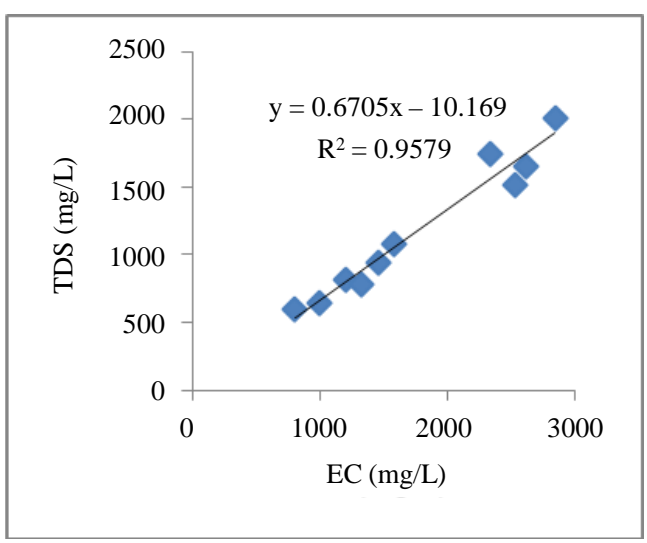

(a)

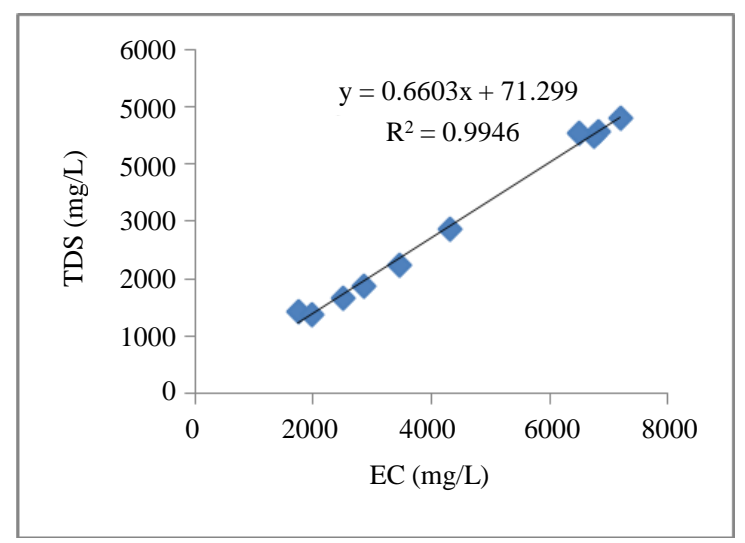

(b)

Figure 2. (a): Scatter diagram showing the correlation between TDS and EC for November 2014 sampling period; (b): Scatter diagram showing the correlation between TDS and EC for January 2015 sampling period.

\section{Turbidity}

Turbidity in water arises from the occurrence of very finely divided solids which are not filterable by routine methods in solution. The observed values of mean turbidity ranged from a minimum of $46.15 \mathrm{NTU}$ at site KAKD to a maximum of 156.40 NTU at NKB in November 2014, Table 3(a) and Table 3(c). January 2015 gave a minimum turbidity value of $152.08 \mathrm{NTU}$ at site KAKD and a maximum value of $397.96 \mathrm{NTU}$ at site ADSK, Table 3(c) and Table 3(d). The control samples also recorded values of 9.16 NTU and 25.54 NTU in the respective months. The overall mean turbidity for all the sites in November 2014 was $89.76 \pm 30.53$ NTU and that for all the sites in January 2015 was $249.22 \pm 68.01$ NTU. In general, all the urban roads recorded very high values of turbidity as compared to those recorded by the highway sites which was probably due to the presence of organic particulate matter on the road surfaces before the storm events. High turbidity values recorded for the road runoffs in January 2015 might be due to the presence of suspended matter such as clay, finely divided organic and inorganic matter, silt and other microscopic organisms which were deposited unto the road surfaces during the antecedent dry harmattan period. These components were washed from the road surfaces into runoffs and this is evidenced by the strong correlation coefficient $\left(\mathrm{R}^{2}=0.796\right.$ and 0.931$)$ observed between Turbidity and TSS for November 2014, Figure 3(a), and January 2015, Figure 3(b), sampling periods respectively [21].

pH

The study revealed that, with the exception of sites KJU and KAKD which recorded mean $\mathrm{pH}$ values of 7.33 and 7.12 respectively in November 2014, Table 3(a), all the road runoffs sampled for both periods were acidic. Mean $\mathrm{pH}$ values ranging from 6.57 at site NKB to 7.33 at site KJU were recorded in November 2014 and 5.03 at site MAV to 6.02 at site KJU in January 2015, Table 3(b). The control samples also showed an acidic trend with the $\mathrm{pH}$ values of 6.51 and 5.57 in the respective months. From Table 3(c) and Table 3(d), the overall mean pH for all the sites had values of $6.81 \pm 0.24$ and $5.61 \pm 0.25$ for November 2014 and January 2015 respectively. This low $\mathrm{pH}$ values in both control and runoff samples might be due to the excessive release of sulphur oxides (SOx) and nitrogen oxides (NOx) from incomplete combustion of fuel from vehicles and the use of power plants and generators by so many households and shops due to the current power crises in Ghana [23].

\section{Chloride}

The observed values of the mean concentration of chloride ranged from a minimum of $15.40 \mathrm{mg} / \mathrm{L}$ at $\mathrm{KJU}$ to a maximum of $38.48 \mathrm{mg} / \mathrm{L}$ at NKB in November 2014, Table 3(c). January 2015 gave a minimum value of $43.08 \mathrm{mg} / \mathrm{L}$ at KJU and a maximum value of $104.13 \mathrm{mg} / \mathrm{L}$ at NKB. The control samples also recorded values $13.10 \mathrm{mg} / \mathrm{L}$ and $28.67 \mathrm{mg} / \mathrm{L}$ in the respective months, Table 3(c) and Table 3(d). The overall mean concentration for all the sites in November 2014 was $25.69 \pm 7.38 \mathrm{mg} / \mathrm{L}$ and that from all the sites in January 2015 was of $69.16 \pm 21.01 \mathrm{mg} / \mathrm{L}$. Higher values of chloride concentrations were recorded for the road runoffs sampled in January 2015, and were more evident in the urban road runoffs as compared to the highway runoffs. These higher concentrations of chloride ion in runoffs sampled from the urban roads might be due to higher traffic intensity and roadside dumping of solid waste since a lot of commercial activities take place in the urban area. 


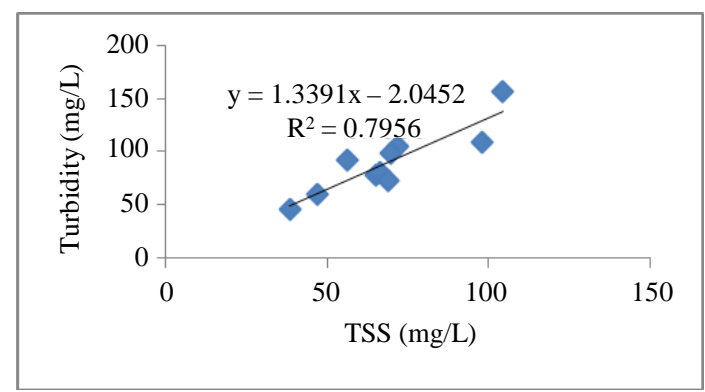

(a)

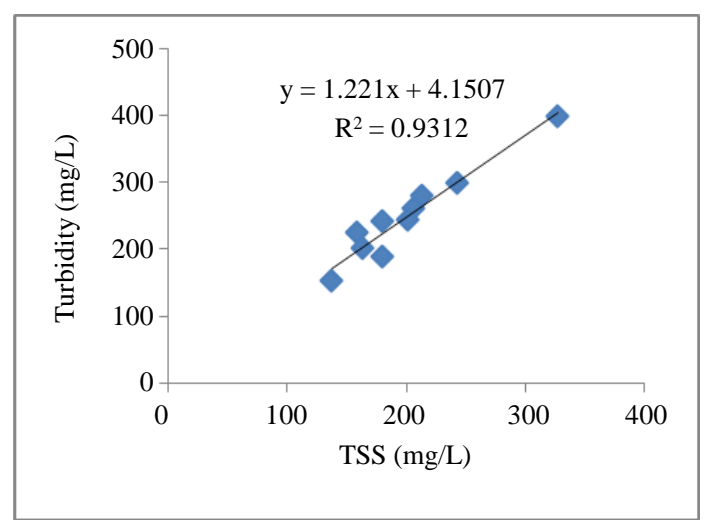

(b)

Figure 3. (a): Scatter diagram showing the correlation between turbidity and TSS for November 2014 sampling period; (b): Scatter diagram showing the correlation between turbidity and TSS for January 2015 sampling period.

\section{Sulphate}

The mean values for sulphate ranged from a minimum of $14.48 \mathrm{mg} / \mathrm{L}$ at site KAKD to a maximum of 58.31 mg/L at NKB in November 2014, Table 3(a). January 2015 gave a minimum value of $51.67 \mathrm{mg} / \mathrm{L}$ at site KJU and a maximum value of $172.15 \mathrm{mg} / \mathrm{L}$ at site MAV, Table 3(b). The control samples recorded values 17.90 $\mathrm{mg} / \mathrm{L}$ and $35.64 \mathrm{mg} / \mathrm{L}$ in the respective months, Table 3(c) and Table 3(d). The overall mean concentration for all the sites in November 2014 was $33.02 \pm 16.23 \mathrm{mg} / \mathrm{L}$ and that from all the sites in January 2015 recorded a value of $96.85 \pm 40.52 \mathrm{mg} / \mathrm{L}$. Higher concentrations of sulphate ion in runoffs sampled from urban roads is probably due to higher traffic intensity as traffic emissions release $\mathrm{SO}_{2}$ into the atmosphere [24].

\section{Phosphate}

The analysis of road runoff samples of the study area showed that the mean values for phosphate ranged from a minimum of $0.04 \mathrm{mg} / \mathrm{L}$ at site TOT2 to a maximum of $10.78 \mathrm{mg} / \mathrm{L}$ at site KJU in November 2014, Table 3(a). January 2015 recorded a minimum value of $2.78 \mathrm{mg} / \mathrm{L}$ at site TOT2 and a maximum value of $37.40 \mathrm{mg} / \mathrm{L}$ at site KAKD, Table 3(c) and Table 3(d). The control samples gave values of $0.043 \mathrm{mg} / \mathrm{L}$ and $0.65 \mathrm{mg} / \mathrm{L}$ in the respective months. The overall mean concentration for all the sites in November 2014 was $4.56 \pm 3.64 \mathrm{mg} / \mathrm{L}$. The mean concentration for all the sites in January 2015 was $15.02 \pm 10.90 \mathrm{mg} / \mathrm{L}$. From the results obtained the concentrations of phosphate in runoffs sampled from highways were higher as compared to those sampled from urban roads and might be probably due to migration of pollutants transported as dust particles from farm lands along the highways onto the road surface which were later carried into the road runoffs during the storm events [19] [25].

\section{Nitrate}

The study revealed that the mean values for nitrate ranged from a minimum of $4.40 \mathrm{mg} / \mathrm{L}$ at site KJU to a maximum of $22.33 \mathrm{mg} / \mathrm{L}$ at site NKB in November 2014, Table 3(a). January 2015 recorded a minimum value of $25.92 \mathrm{mg} / \mathrm{L}$ at site $\mathrm{KJU}$ and a maximum value of $87.33 \mathrm{mg} / \mathrm{L}$ at site MAV, Table 3(b). The control samples had values of $2.10 \mathrm{mg} / \mathrm{L}$ and $16.30 \mathrm{mg} / \mathrm{L}$ in the respective months, Table 3(c) and Table 3(d). The overall mean nitrate ion concentrations for all the sites in November 2014 was $13.41 \pm 5.19 \mathrm{mg} / \mathrm{L}$ while that for all the sites in January 2015 was $48.60 \pm 21.65 \mathrm{mg} / \mathrm{L}$. Most of the sites that recorded high nitrate ion concentrations were among the urban roads and this is as a result of dry deposition of nitrous oxides from countless sources, including automobile exhaust, industrial emissions, and other anthropogenic activities. These nitrous oxides can react with water to form nitric acid, $\mathrm{HNO}_{3}$, which dissociates in solution, leading to an increase in $\mathrm{NO}_{3}^{-}$concentrations in storm water [26].

\section{Heavy Metals}

Analysis of road runoff samples from the study area, Figure 1(a) and Figure 1(b), for heavy metals showed that the concentration of iron (Fe) ranged from a minimum of $0.007 \mathrm{mg} / \mathrm{L}$ at site ADSK to a maximum of 0.561 $\mathrm{mg} / \mathrm{L}$ at site ADWE in November 2014, Table 4(a). January 2015 had a minimum value of $0.695 \mathrm{mg} / \mathrm{L}$ at site TOT 2 and a maximum value of $4.906 \mathrm{mg} / \mathrm{L}$ at site ADWE, Table 4(b), (Figure 4(a) and Figure 4(b)). The 
Table 4. (a): Heavy metal concentrations from samples road runoffs in November 2014; (b): Mean concentrations of heavy metals in the road runoffs sampled in January 2015; (c): Statistical summary of heavy metals in road runoffs sampled from all the sites in November 2014; (d): Statistical summary of heavy metals in road runoffs sampled from all the sites in January 2015.

(a)

\begin{tabular}{|c|c|c|c|c|c|c|c|c|c|c|}
\hline \multirow{2}{*}{ Trace metals } & \multicolumn{5}{|c|}{ Urban roads } & \multicolumn{5}{|c|}{ Highways } \\
\hline & MAV & OLR & NKB & TOT 2 & ADSK & KJU & KAKD & KNK & KASJ & ADWE \\
\hline $\mathrm{Fe}(\mathrm{mg} / \mathrm{L})$ & 0.008 & 0.063 & 0.136 & 0.115 & 0.007 & 0.351 & 0.09 & 0.172 & 0.400 & 0.561 \\
\hline $\mathrm{Cu}(\mathrm{mg} / \mathrm{L})$ & 0.135 & 0.020 & 0.165 & 0.038 & 0.151 & 0.016 & 0.017 & 0.014 & 0.023 & 0.047 \\
\hline $\mathrm{Cd}(\mathrm{mg} / \mathrm{L})$ & BDL & BDL & BDL & 0.003 & 0.002 & 0.005 & 0.075 & 0.005 & 0.008 & 0.004 \\
\hline $\mathrm{Pb}(\mathrm{mg} / \mathrm{L})$ & 0.104 & 0.083 & 0.150 & 0.095 & 0.152 & 0.029 & 0.009 & 0.023 & 0.060 & 0.101 \\
\hline Zn (mg/L) & 0.084 & 0.033 & 0.167 & 0.035 & 0.233 & 0.017 & 0.027 & 0.018 & 0.031 & 0.044 \\
\hline $\mathrm{Ni}(\mathrm{mg} / \mathrm{L})$ & BDL & BDL & 0.002 & BDL & BDL & 0.003 & BDL & 0.002 & 0.005 & 0.006 \\
\hline $\mathrm{Cr}(\mathrm{mg} / \mathrm{L})$ & BDL & BDL & BDL & BDL & BDL & BDL & BDL & BDL & BDL & BDL \\
\hline
\end{tabular}

$\mathrm{BDL}=$ below detection limit.

(b)

\begin{tabular}{|c|c|c|c|c|c|c|c|c|c|c|}
\hline \multirow{2}{*}{ Trace metals } & \multicolumn{5}{|c|}{ Urban roads } & \multicolumn{5}{|c|}{ Highways } \\
\hline & MAV & OLR & NKB & тОт 2 & ADSK & KJU & KAKD & KNK & KASJ & ADWE \\
\hline $\mathrm{Fe}(\mathrm{mg} / \mathrm{L})$ & 2.311 & 2.581 & 2.578 & 0.695 & 1.175 & 3.212 & 4.270 & 2.731 & 2.744 & 4.906 \\
\hline $\mathrm{Cu}(\mathrm{mg} / \mathrm{L})$ & 1.474 & 0.243 & 2.205 & 1.256 & 0.261 & 0.141 & 0.117 & 0.198 & 0.135 & 0.199 \\
\hline Cd (mg/L) & 0.081 & 0.018 & 0.018 & 0.015 & 0.016 & 0.009 & 0.067 & 0.282 & 0.027 & 0.021 \\
\hline $\mathrm{Pb}(\mathrm{mg} / \mathrm{L})$ & 2.345 & 0.429 & 1.788 & 1.105 & 0.835 & 0.084 & 0.039 & 0.035 & 0.039 & 0.656 \\
\hline Zn (mg/L) & 2.256 & 0.851 & 2.205 & 1.623 & 1.622 & 0.797 & 0.783 & 0.729 & 0.405 & 1.594 \\
\hline $\mathrm{Ni}(\mathrm{mg} / \mathrm{L})$ & 0.085 & 0.448 & 0.437 & 0.422 & 0.423 & 0.618 & 0.772 & 0.492 & 0.524 & 1.623 \\
\hline $\mathrm{Cr}(\mathrm{mg} / \mathrm{L})$ & 0.274 & 0.492 & 0.456 & 0.328 & 0.312 & 0.676 & 0.718 & 0.602 & 0.656 & 0.738 \\
\hline
\end{tabular}

(c)

\begin{tabular}{lccccccc}
\hline & Minimum & Maximum & Mean & Std. Dev. & Kurtosis & Skewness & Control sample \\
\hline $\mathrm{Fe}(\mathrm{mg} / \mathrm{L})$ & 0.007 & 0.561 & 0.190 & 0.19 & 0.119 & 1.056 & 0.005 \\
$\mathrm{Cu}(\mathrm{mg} / \mathrm{L})$ & 0.014 & 0.165 & 0.063 & 0.062 & -1.061 & 0.985 & 0.004 \\
$\mathrm{Cd}(\mathrm{mg} / \mathrm{L})$ & 0.002 & 0.075 & 0.015 & 0.027 & 6.887 & 2.618 & BDL \\
$\mathrm{Pb}(\mathrm{mg} / \mathrm{L})$ & 0.009 & 0.152 & 0.081 & 0.050 & -1.083 & 0.02 & 0.001 \\
$\mathrm{Zn}(\mathrm{mg} / \mathrm{L})$ & 0.017 & 0.233 & 0.069 & 0.073 & 2.002 & 1.712 & 0.002 \\
$\mathrm{Ni}(\mathrm{mg} / \mathrm{L})$ & 0.002 & 0.006 & 0.004 & 0.002 & -2.231 & 0.567 & BDL \\
$\mathrm{Cr}(\mathrm{mg} / \mathrm{L})$ & BDL & - & - & - & - & - & BDL \\
\hline
\end{tabular}

$\mathrm{BDL}=$ below detection limit.

(d)

\begin{tabular}{cccccccc}
\hline & Minimum & Maximum & Mean & Std. Dev. & Kurtosis & Skewness & Control sample \\
\hline Fe (mg/L) & 0.695 & 4.906 & 2.72 & 1.252 & 0.202 & 0.156 & 0.212 \\
$\mathrm{Cu}(\mathrm{mg} / \mathrm{L})$ & 0.117 & 2.205 & 0.623 & 0.745 & 0.794 & 0.018 \\
$\mathrm{Cd}(\mathrm{mg} / \mathrm{L})$ & 0.009 & 0.282 & 0.055 & 0.083 & 7.749 & 2.716 & 1.082 \\
$\mathrm{~Pb}(\mathrm{mg} / \mathrm{L})$ & 0.035 & 2.345 & 0.736 & 0.805 & 0.267 & 0.298 \\
$\mathrm{Zn}(\mathrm{mg} / \mathrm{L})$ & 0.405 & 2.256 & 1.287 & 0.656 & -1.41 & 0.008 \\
$\mathrm{Ni}(\mathrm{mg} / \mathrm{L})$ & 0.085 & 1.623 & 0.584 & 0.404 & 5.727 & 2.078 \\
$\mathrm{Cr}(\mathrm{mg} / \mathrm{L})$ & 0.274 & 0.738 & 0.525 & 0.177 & -1.694 & -0.267 \\
\hline
\end{tabular}

$\mathrm{BDL}=$ below detection limit. 


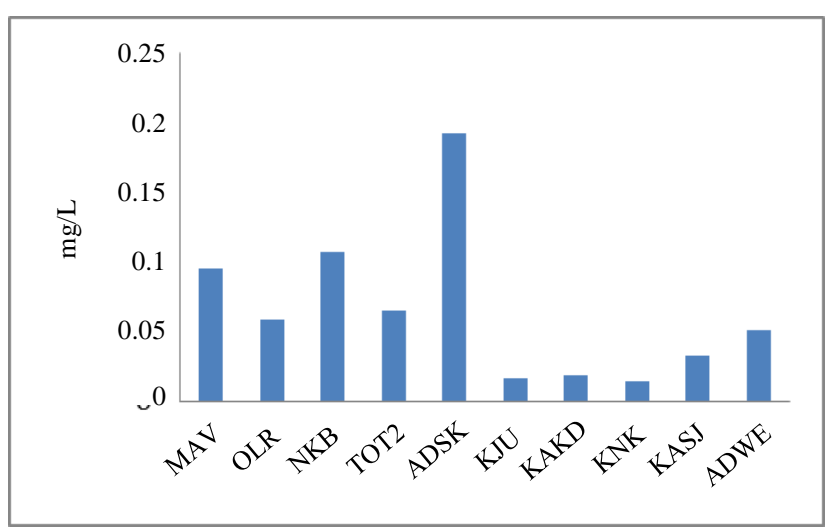

(a)

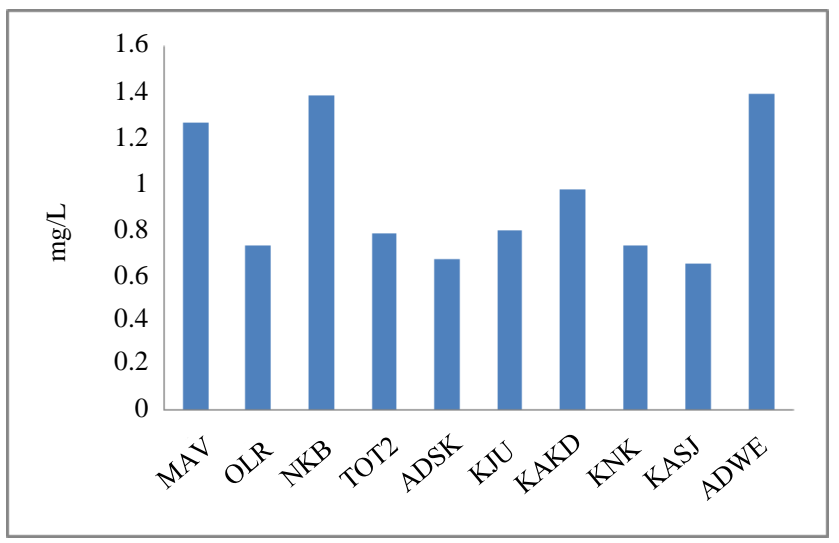

(b)

Figure 4. (a): The overall mean concentration of heavy metals for the various sampling sites in November 2014; (b): The overall mean concentration of heavy metals for the various sampling sites in January 2015.

control samples recorded values of $0.005 \mathrm{mg} / \mathrm{L}$ and $0.212 \mathrm{mg} / \mathrm{L}$ in the respective months, Table 4(c) and Table 4(d). The overall mean iron concentration for all the sites in November 2014 was $0.190 \pm 0.185 \mathrm{mg} / \mathrm{L}$ and that for all the sites in January 2015 was $2.720 \pm 1.252 \mathrm{mg} / \mathrm{L}$. The results obtained show that concentrations of iron in runoffs sampled from highways were higher as compared to those sampled from urban roads and might be probably due to vehicular deposition. The relatively high levels of Fe in vehicular emissions could partly be due to brake wear and muffler abrasions [11] [27]. However, the high concentration of Fe could also be attributed to the automobile exhausts, corrosion products of metal surfaces that are commonly used as roofing materials in the study area [23].

Total copper $(\mathrm{Cu})$ concentrations in highway and urban road runoffs is derived in part from its use in automobile brake pads for some types of automobiles and can exceed water quality standards [19]. The observed values of the mean concentration of copper ranged from a minimum of $0.014 \mathrm{mg} / \mathrm{L}$ at site $\mathrm{KNK}$ to a maximum of 0.165 $\mathrm{mg} / \mathrm{L}$ at site NKB in November 2014, Table 4(a). January 2015 also recorded a minimum value of $0.117 \mathrm{mg} / \mathrm{L}$ at site KAKD and a maximum value of $2.205 \mathrm{mg} / \mathrm{L}$ at site NKB, Table 4(b). The control samples had values of $0.004 \mathrm{mg} / \mathrm{L}$ and $0.018 \mathrm{mg} / \mathrm{L}$ in the respective months, Table 4(c) and Table 4(d). The overall mean copper concentrations for all the sites in November 2014 was $0.063 \pm 0.062 \mathrm{mg} / \mathrm{L}$ and that for January 2015 was 0.623 $\pm 0.745 \mathrm{mg} / \mathrm{L}$. The most likely source for $\mathrm{Cu}$ in the road runoff is the wear of brake linings of passenger cars and moving engine parts and tyre wear [27]-[29].

Cadmium (Cd) is released into the environment from mining and metal processing operations, burning fuels, making and using phosphate fertilizers, and disposing of metal products. Cd is also used for electroplating and for pigments present in paint, printing ink, and plastics [30]. 
The study revealed that the mean concentration of cadmium determined ranged from $0.002 \mathrm{mg} / \mathrm{L}$ at site ADSK to a maximum value of $0.075 \mathrm{mg} / \mathrm{L}$ at site KAKD but was not determined at sites MAV, OLR and NKB in November 2014, Table 4(a). January 2015 gave a minimum value of $0.009 \mathrm{mg} / \mathrm{L}$ at $\mathrm{KJU}$ and a maximum value of $0.282 \mathrm{mg} / \mathrm{L}$ at site KNK. The concentration of cadmium in the control samples also fell below detection limit of $0.001 \mathrm{mg} / \mathrm{L}$. The overall mean cadmium concentration for all the sites in November 2014 recorded a value of $0.015 \pm 0.027 \mathrm{mg} / \mathrm{L}$ and that for all the sites in January 2015 recorded a value of $0.055 \pm 0.083 \mathrm{mg} / \mathrm{L}$. The levels of $\mathrm{Cd}$ in the road runoffs could also be due to the leakage of lubricating oils and wearing of old tyres [30] [11]. The harmful impacts of Cd include reduced growth and development, cancer, organ damage in males (sterility), nervous system damage in man from drinking such water [31].

The former use of lead as an additive in gasoline as an anti-knock agent caused highway and urban road runoffs to contain higher concentration of lead. Despite the phasing out of leaded gasoline, naturally occurring lead in gasoline can be on the order of $15 \mathrm{mg} / \mathrm{L}$ which might cause highway and urban road runoffs to contain sufficient concentration of lead in violation of water quality standards. Pb is of greatest concern because lead in soluble form is very stable, most toxic and difficult to eliminate [32]. The mean concentration of lead ranged from a minimum of $0.009 \mathrm{mg} / \mathrm{L}$ at site KAKD to a maximum of $0.152 \mathrm{mg} / \mathrm{L}$ at site ADSK in November 2014, Table 4(a). January 2015 also recorded a minimum value of $0.035 \mathrm{mg} / \mathrm{L}$ at site $\mathrm{KNK}$ and a maximum value of $2.345 \mathrm{mg} / \mathrm{L}$ at site MAV, Table 4(b). The control samples gave values of $0.001 \mathrm{mg} / \mathrm{L}$ and $0.008 \mathrm{mg} / \mathrm{L}$ in the respective months. The overall mean lead concentrations for all the sites in November 2014 was $0.081 \pm 0.050$ $\mathrm{mg} / \mathrm{L}$. January 2015 recorded an overall mean value of $0.736 \pm 0.805 \mathrm{mg} / \mathrm{L}$. The high concentrations of lead in the sampled runoffs might be probably due to the use of lead-containing paints on vehicles, tyre and brake linings abrasions as well as bearing wear and other sources of $\mathrm{Pb}[11]$.

Zinc (Zn) has lots of use including galvanization of steel, preparation of negative plates in electric batteries, vulcanization of rubber, wood preservatives, antiseptics and in rat and mouse poison (Zn-phosphide). Very low amount of the Zn may cause loss of appetite, decreased sense of taste and smell, slow wound healing and skin sores [29]. The observed values of mean concentration of Zinc determined ranged from $0.017 \mathrm{mg} / \mathrm{L}$ at site KJU to a maximum value of $0.233 \mathrm{mg} / \mathrm{L}$ at site ADSK in November 2014, Table 4(a). January 2015 also recorded a minimum value of $0.405 \mathrm{mg} / \mathrm{L}$ at site KASJ and a maximum value of $2.256 \mathrm{mg} / \mathrm{L}$ at site MAV, Table 4(b). The control samples recorded values of $0.002 \mathrm{mg} / \mathrm{L}$ and $0.181 \mathrm{mg} / \mathrm{L}$ in the respective months, Table 4(c) and Table 4(d). The overall mean zinc concentration for all the sites in November 2014 was $0.069 \pm 0.073 \mathrm{mg} / \mathrm{L}$ while that of January 2015 was $1.287 \pm 0.656 \mathrm{mg} / \mathrm{L}$. The high concentrations of $\mathrm{Zn}$ recorded for the various sampling sites was as a result of the fact that $\mathrm{Zn}$ is an additive in motor oil that is mixed with the gasoline in two-stroke engine and poorly functioning engines particularly those with leaky piston rings burn more lubricating oil and release $\mathrm{Zn}$ into the atmosphere which are then washed off and carried in the road runoffs during a storm event [11].

The study revealed that the mean concentration of nickel (Ni) determined ranged from $0.002 \mathrm{mg} / \mathrm{L}$ at sites $\mathrm{NKB}$ and KNK to a maximum value of $0.006 \mathrm{mg} / \mathrm{L}$ at site ADWE but was not determined at sites MAV, OLR, TOT2, ADSK and KAKD in November 2014, Table 4(a). January 2015 recorded nickel concentration at all sites with a minimum value of $0.085 \mathrm{mg} / \mathrm{L}$ at $\mathrm{MAV}$ and a maximum value of $1.623 \mathrm{mg} / \mathrm{L}$ at ADWE. The concentration of $\mathrm{Ni}$ in the control samples fell below detection limit in November 2014 but recorded a value of $0.011 \mathrm{mg} / \mathrm{L}$ in January 2015. The overall mean nickel concentration for all the sites in November 2014 was $0.004 \pm 0.002 \mathrm{mg} / \mathrm{L}$. January 2015 recorded a value of $0.584 \pm 0.404 \mathrm{mg} / \mathrm{L}$. Since no major industry exists in the study areas such as smelting operations, we may assume that the primary sources of $\mathrm{Ni}$ are probably the attrition of motor vehicle tyre rubber, discharge of lubrication oil and grease as well as vehicular component wears deposited onto the surface of the roads. Other sources of $\mathrm{Ni}$ are diesel fuel exhaust, asphalt paving and metal plating [33]. The most common type of reaction to Ni exposure is a skin rash at the site of contact. Skin contact with metallic or soluble Ni compounds can produce allergic dermatitis [29].

Chromium was not detected at all sampling sites as well as in the control samples in November 2014. However, in January 2015 the sampling sites recorded incredible high concentrations of chromium with mean values ranging from a minimum of $0.274 \mathrm{mg} / \mathrm{L}$ at site $\mathrm{MAV}$ to $0.738 \mathrm{mg} / \mathrm{L}$ at site ADWE. The chromium concentration in the control samples fell below detection limit. An overall mean value of $0.525 \pm 0.177 \mathrm{mg} / \mathrm{L}$ was recorded for all the sampling sites in January 2015. Higher concentrations of $\mathrm{Cr}$ in sampled road runoffs might be due to vehicular depositions and also the fact that a lot of building constructions are on-going along the highways since chromium is used in metal alloys and pigment for cement [31]. 


\section{Statistical Analysis}

The statistical summary of the physico-chemical parameters of highway and urban road runoff water samples for the November 2014 and the January 2015 sampling periods are presented in Table 3(a) and Table 3(b) respectively. Negative value of kurtosis for the parameters EC, TDS, Sulphate, and Phosphate in November 2014, Table 3(c), shows a flat distribution around the study area and the positive value of kurtosis for the remaining parameters shows non-uniform distribution around the study area. The skewness values point towards sharp physico-chemical distribution with a long right tail.

The negative value of kurtosis recorded for the parameters temperature, EC, TDS, chloride and nitrate in January 2015, Table 3(d), shows a flat distribution around the study area and the positive value of kurtosis for the remaining parameters shows a non-uniform distribution around the study area. Apart from the $\mathrm{pH}$ which recorded a negative value of skewness, all the parameters in January 2015 recorded positive value of skewness which gives a distribution with a significant long right tail, and the $\mathrm{pH}$ giving a distribution with a significant long left tail.

The $\mathrm{pH}$ values of both control sample and the road runoffs were acidic, which is mainly due to a high concentration of $\mathrm{SO}_{4}^{2-}$ and $\mathrm{NO}_{3}^{-}$components. Therefore a correlational analysis was performed to ascertain which of the anions had a greater influence on the acidity of the sampled road runoffs as well as the control samples. However, it was concluded that the higher values of $\mathrm{SO}_{4}^{2-}$ compared to $\mathrm{NO}_{3}^{-}$at all the sampling sites indicates that $\mathrm{SO}_{2}$ impacted more on the acidity of the road runoff samples even though both sulphate and nitrate correlated strongly with the $\mathrm{pH}$ values recorded for both sampling events Figures 5(a)-(d).

The statistical summary of heavy metals in the highway and urban road runoff water samples for the November 2014 and the January 2015 sampling periods are presented in Table 4(c) and Table 4(d) respectively. Negative value of kurtosis for the heavy metals $\mathrm{Cu}, \mathrm{Pb}$ and $\mathrm{Ni}$ in November 2014 show a flat distribution around the study area and the remaining showed non-uniform distribution having significant positive kurtosis. The skewness values point towards heavy metals distribution with a long right tail for the road runoffs sampled in November 2014. The negative value of kurtosis recorded for the heavy metals $\mathrm{Zn}$ and $\mathrm{Cr}$ in January 2015, show a flat distribution around the study area and the positive value of kurtosis for the remaining parameters show a non-uniform distribution around the study area. Apart from $\mathrm{Cr}$ which recorded a negative value of skewness, all the parameters in January 2015 recorded positive value of skewness which gives a distribution with a significant long right tail with Cr giving a distribution with a significant long left tail.

Based on the location analysis of the quality of road runoffs, it is observed that site KAKD recorded the least overall mean concentration of heavy metals $(0.018 \mathrm{mg} / \mathrm{L})$ while site ADSK recorded the highest overall concentration of heavy metals $(0.193 \mathrm{mg} / \mathrm{L})$ for the road runoffs sampled in November 2014. The January 2015 road runoff analysis showed site ADWE recording the highest overall mean concentration of heavy metals (1.391 $\mathrm{mg} / \mathrm{L})$ while KASJ gave the least overall mean concentration of heavy metals $(0.647 \mathrm{mg} / \mathrm{L})$. The road runoffs sampled in January 2015 recorded relatively higher concentrations of heavy metals which indicate that there was accumulation of heavy metals as a result of depositions from vehicles and other automobiles during the antecedent dry weather period. However, the highly acidic nature of the early rains in January 2015 also contributed to the high levels of heavy metals in the sampled road runoffs since they are able to wash off most of the heavy metal contaminants from the road surfaces.

The abundance order, Figure 6, of the heavy metals in the road runoffs sampled in November 2014 followed the sequence $\mathrm{Fe}>\mathrm{Pb}>\mathrm{Zn}>\mathrm{Cu}>\mathrm{Cd}>\mathrm{Ni}>\mathrm{Cr}$. However the abundance order for the road runoffs sampled in January 2015 followed the sequence $\mathrm{Fe}>\mathrm{Zn}>\mathrm{Pb}>\mathrm{Cu}>\mathrm{Ni}>\mathrm{Cr}>\mathrm{Cd}$.

Correlational analysis, Figure 7 and Figure 8, was performed for some selected heavy metals measured in the road runoff samples because knowing the relationships between constituents can reveal their possible sources. In the present study, the data exhibited a skewed, non-normal distribution indicated by the differences found between the median and mean values of the runoff water concentrations. Most parameters significantly deviated from normal distribution. Due to the non-normal distribution of most parameters, the Pearson correlation, used for example by Demirak et al. [34] cannot be applied as it requires normal distribution values. However, the degree of correlation between some of the heavy metal pairs is very low so the diagrams as well as the values are not given which gives a clear indication that the element pairs may not have similar anthropogenic sources.

According to Göbel et al. [24] tyre abrasion determines pollutants like rubber, soot and heavy metal oxides with $\mathrm{Zn}, \mathrm{Pb}, \mathrm{Cr}, \mathrm{Cu}$ and $\mathrm{Ni}$ while brake pad abrasion determines $\mathrm{Ni}, \mathrm{Cr}, \mathrm{Cu}$ and $\mathrm{Pb}$. Some specific sources of heavy metal pollutants from vehicle originate from tetraethyl lead in gasoline $(\mathrm{Pb})$, diesel oil $(\mathrm{Cd})$, tyre abrasion 


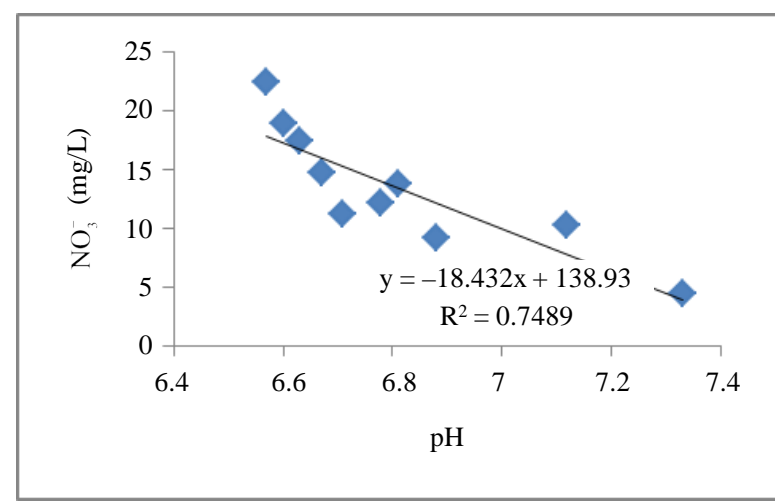

(a)

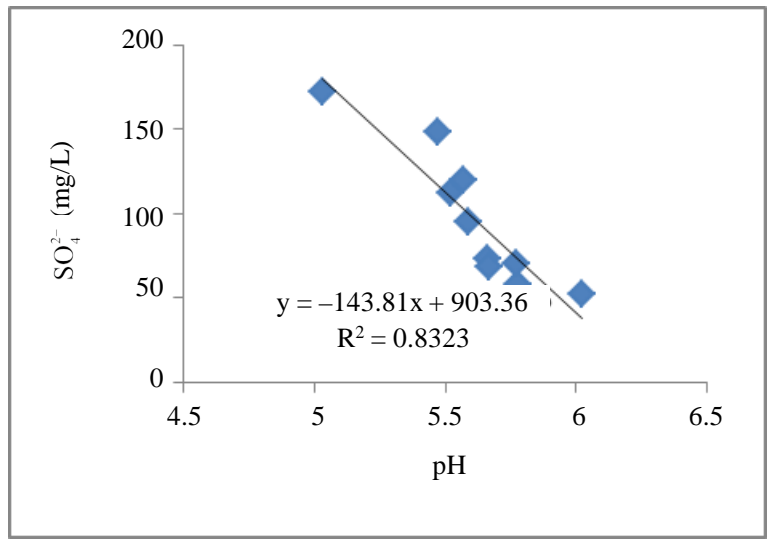

(c)

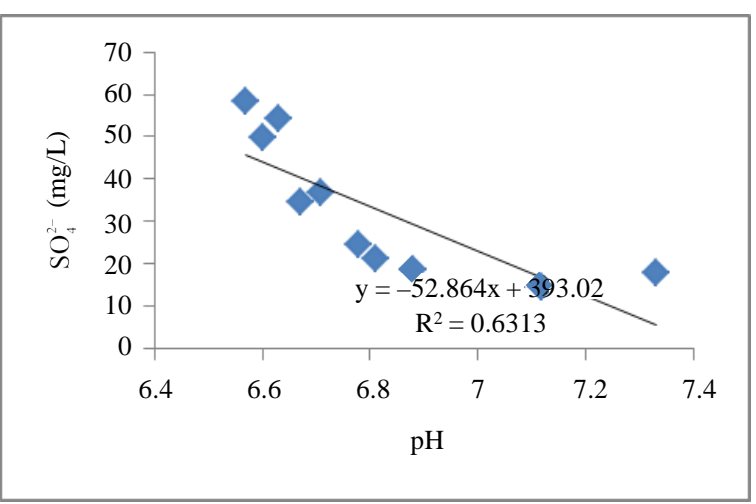

(b)

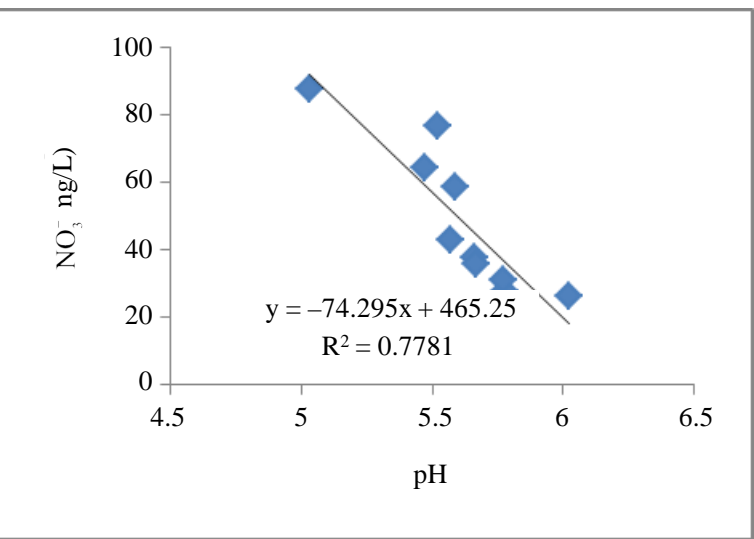

(d)

Figure 5. (a) and (b): Scatter diagram showing how the $\mathrm{pH}$ correlates with $\mathrm{NO}_{3}^{-}$and $\mathrm{SO}_{4}^{2-}$ for November 2014 sampling period; (c) and (d): Scatter diagram showing how the $\mathrm{pH}$ correlates with $\mathrm{NO}_{3}^{-}$and $\mathrm{SO}_{4}^{2-}$ for January 2015 sampling period.

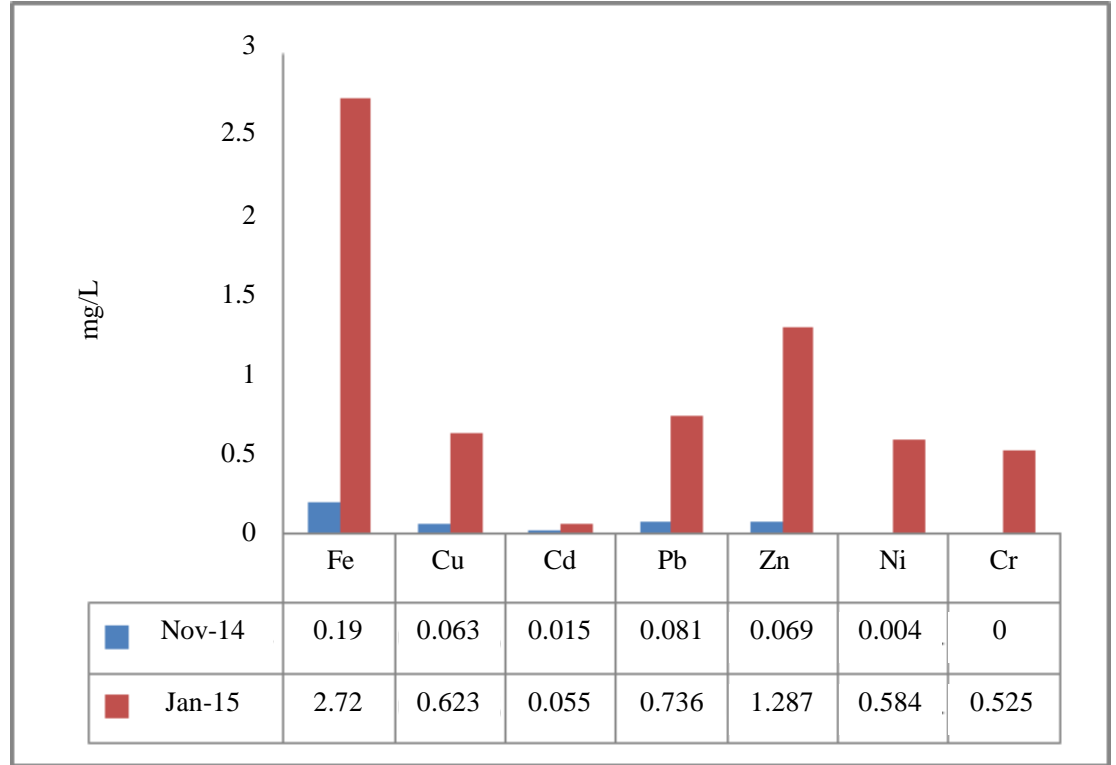

Figure 6. Abundance order of heavy metals in road runoffs sampled in November 2014 and January 2015. 


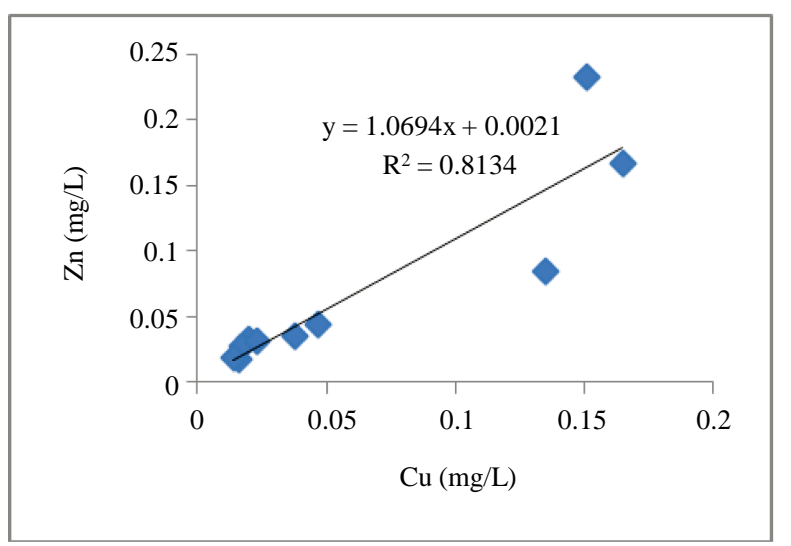

(a)

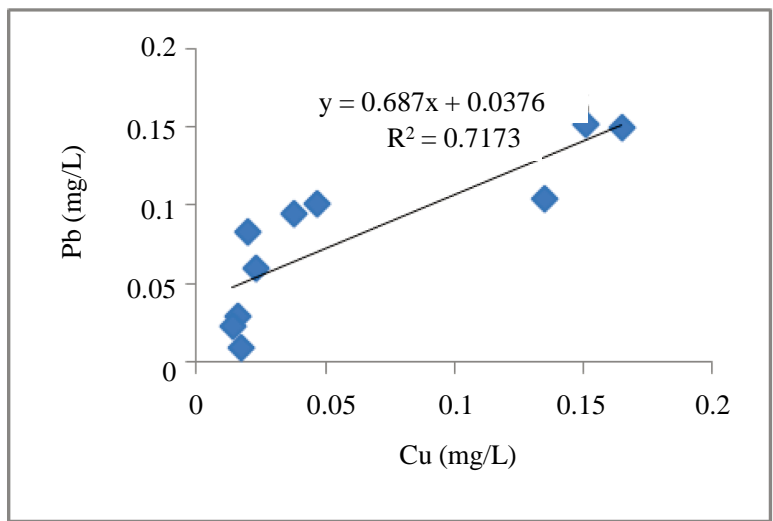

(c)

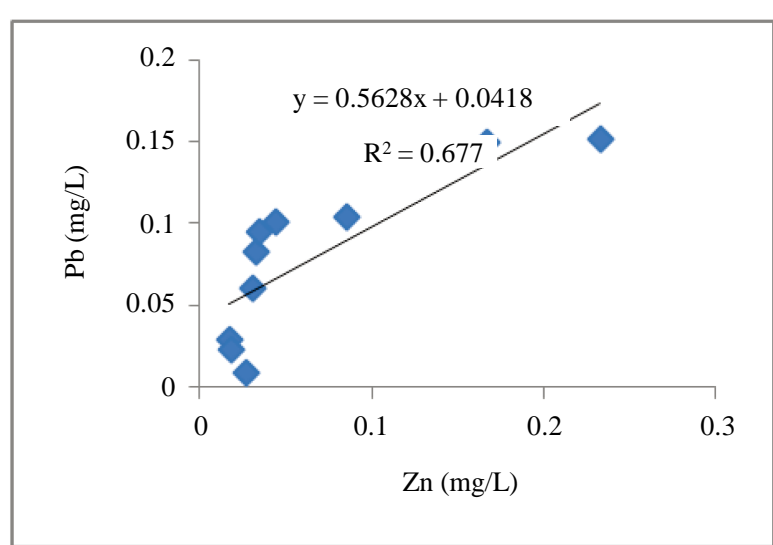

(b)

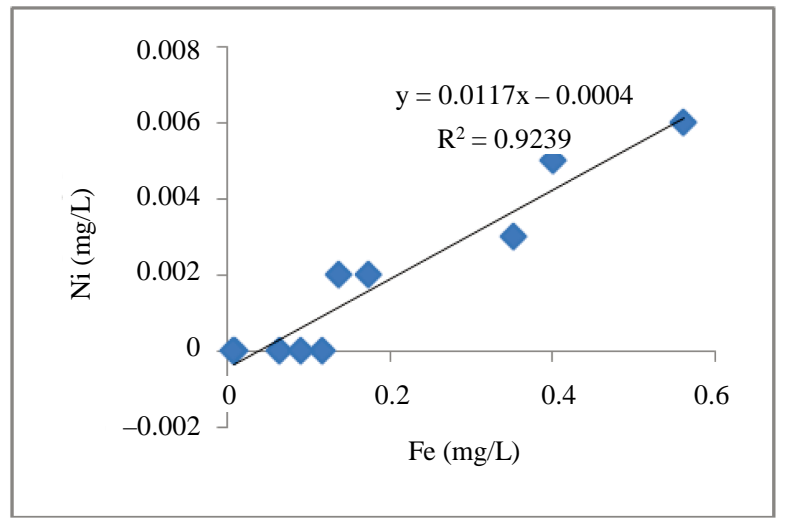

(d)

Figure 7. Relationships between the concentrations of heavy metals in road runoff sampled in November 2014; (a) Zn and $\mathrm{Cu}$; (b) $\mathrm{Zn}$ and $\mathrm{Pb}$; (c) $\mathrm{Cu}$ and $\mathrm{Pb}$; (d) Ni and Fe.

(Zn and $\mathrm{Cd})$, steel part abrasion ( $\mathrm{Ni}, \mathrm{Cr}$ and $\mathrm{Fe}$ ), brake drums $(\mathrm{Fe})$, wear of bearings and bushing $(\mathrm{Cu})$, wire corrosion and break lining abrasion ( $\mathrm{Pb}, \mathrm{Cu}$ and $\mathrm{Zn}$ ) radiator fluid (Cu) [28] [35] [36]. According to Ofosu et al. [11], heavy metals such as $\mathrm{Zn}, \mathrm{Cd}, \mathrm{Ni}$ and $\mathrm{Pb}$ can also be found in motor oil, lubricating oil and grease. Statistical analysis, Figures 7(a)-8(e), performed with excel showed a good correlation between some of the heavy metals in the road runoffs sampled for both periods indicating that the contamination of road runoffs by metals originated from a common anthropogenic source, with automobiles probably, as a major common source due to the absence of any metal industry in the municipality.

\section{Conclusions}

In the absence of any major industry within the municipality, it can be concluded that automobiles contribute many important heavy metals to road surface particulates which are carried by storm water as runoffs and finally into receiving surface waters. The results obtained confirm that highway and urban road runoffs carry large amounts of pollutants that contribute to the degradation of the environment as a result of commercial activities and indirect depositions of pollutants by vehicles that carry various solid materials from construction sites and dirty roads onto the highways and urban roads within the municipality.

The urban roads recorded very high concentration relative to the highways for most of the measured parameters which was probably due to the high traffic intensity and commercial activities in the urban region of the municipality. Generally, the road runoffs recorded high values relative to the control samples for all measured constituents. Comparing the road runoff constituent loads with the recommended maximum values for permissible effluent discharge limits, it is found that a sizeable number of the runoffs were polluted with dissolved solids which accounted for the high values of EC recorded for both sampling periods. Highways and urban roads were 


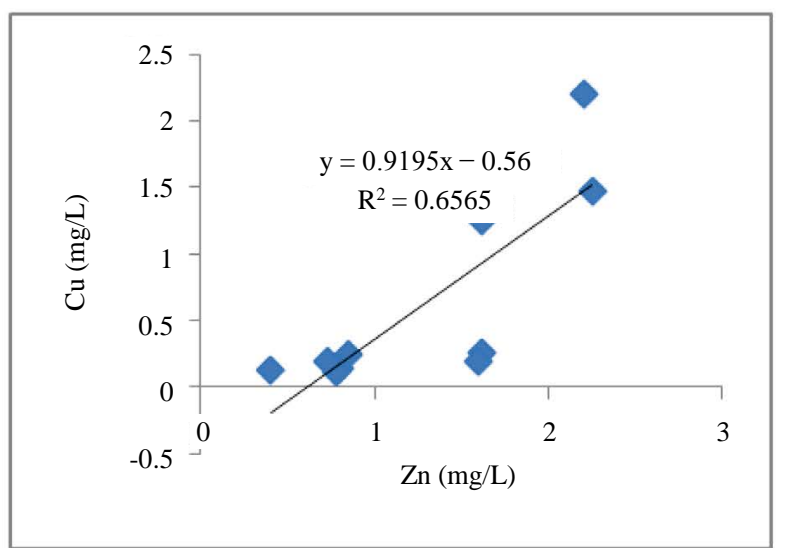

(a)

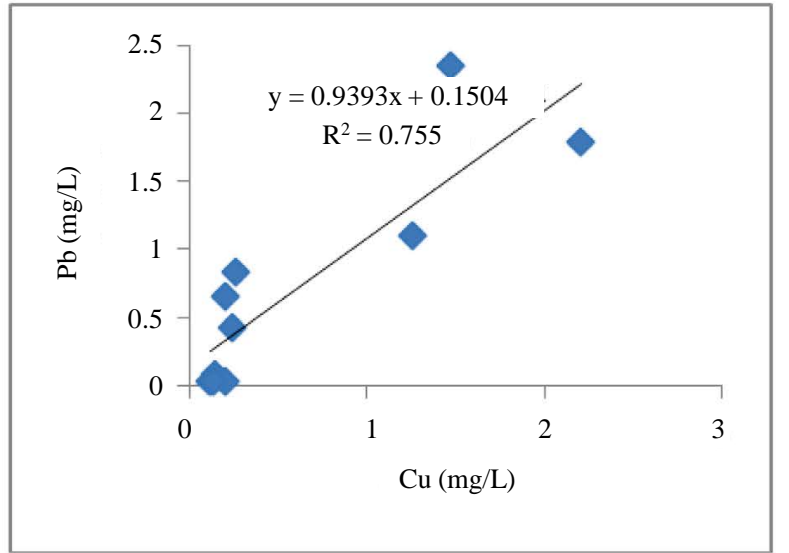

(c)

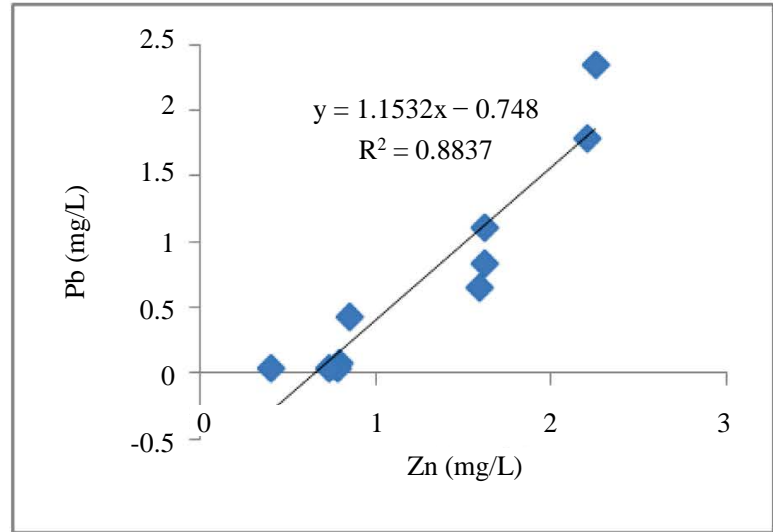

(b)

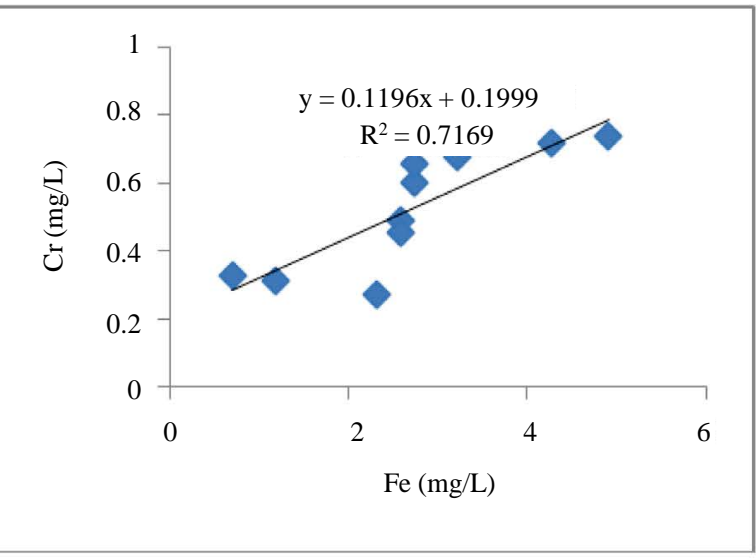

(d)

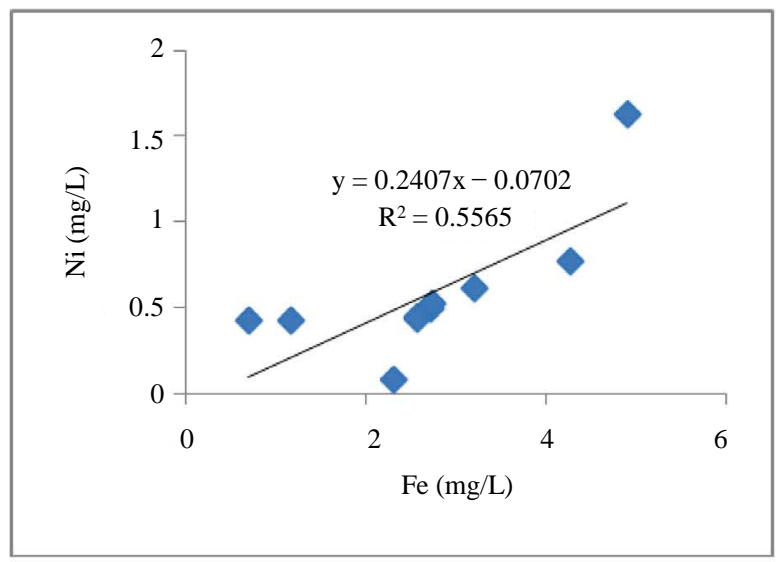

(e)

Figure 8. Relationships between the concentrations of heavy metals in road runoffs sampled in January 2015; (a) $\mathrm{Zn}$ and $\mathrm{Cu}$; (b) $\mathrm{Zn}$ and $\mathrm{Pb}$; (c) $\mathrm{Cu}$ and $\mathrm{Pb}$; (d) $\mathrm{Cr}$ and Fe; (e) Fe and Ni.

highly polluted in terms of solids because the TSS values recorded were above the levels of permitted wastewater discharge limits defined by the Ghana EPA.

Iron $(\mathrm{Fe})$ recorded the highest overall mean concentration of heavy metals for both sampling periods. Cr was not detected at all the sampling sites during the November 2014 sampling period but surprisingly recorded an overall mean value of $0.525 \mathrm{mg} / \mathrm{L}$ for the road runoffs sampled in January 2015 and this might be due to brake pad abrasions as well as steel part abrasions onto the road surface during the antecedent dry period. However, 
Cd recorded the least overall mean heavy metal concentration of 0.055mg/L for the January 2015 sampled road runoffs.

Furthermore, the measured concentrations for $\mathrm{Ni}$ and $\mathrm{Cr}$ for the entire highway sites were above the Ghana EPA limit for the road runoff sampled in January 2015, but none of the urban roads in both periods recorded any mean value above the Ghana EPA set limit. Moreover, the mean concentrations for $\mathrm{Zn}$ and $\mathrm{Cu}$ for all the sampling sites for both periods were within the Ghana EPA limits. The mean concentration for Cd recorded for the various sites for both periods were all within the Ghana EPA limit except for site KNK which recorded a mean value above the limit for the road runoffs sampled in January 2015. $\mathrm{Pb}$ on the other hand recorded mean values within the set Ghana EPA limit for all the sites in both periods with the exception of the urban road sites in January 2015. Surprisingly ADWE was the only highway site that recorded a mean value for $\mathrm{Pb}$ above the Ghana EPA limit and this might be due to the fact that it was the only highway site which was located within the urban region of the municipality.

There was a substantial increase in the concentration of all the studied constituents in both the runoff and the control samples during the January 2015 as compared to the November 2014 sampling period. This general trend could be attributed to the dry depositions of pollutants onto the road surface as a result of the harmattan during the antecedent dry weather period between the sampling periods.

\section{References}

[1] Polkowska, Z., Zabiegała, B., Górecki, T. and Namieśnik, J. (2005) Contamination of Runoff Waters from Roads with High Traffic Intensity in the Urban Region of Gdańsk, Poland. Polish Journal of Environmental Studies, 14, 799-807.

[2] Hou, P., Ren, Y., Zhang, Q., Lu, F., Ouyang, Z. and Wang, X. (2012) Nitrogen and Phosphorous in Atmospheric Deposition and Roof Runoff. Polish Journal of Environmental Studies, 21, 1621-1627.

[3] Armah, F.A., Yawson, D.O. and Pappoe, A.A.N.M. (2010) A Systems Dynamics Approach to Explore Traffic Congestion and Air Pollution Link in the City of Accra, Ghana. Sustainability, 2, 252-265. http://dx.doi.org/10.3390/su2010252

[4] Fortes, M. (2006) Seas of East Asia. The State of the Marine Environment: Regional Assessments, UNEP/GPA, The Hague, 177-192.

[5] U.S. EPA (1983) Results of the Nationwide Urban Runoff Program.

[6] Ahimah, J.K. and Ofosu, S.A. (2012) Evaluation of the Quality of Sachet Water Vended in the New Juaben Municipality of Ghana. International Journal of Water Resources and Environmental, 4, 134-138.

[7] Ambade, B. (2014) Chemical Composition of Runoff Water in Raipur City, Central India. Applied Water Science, 5, 112. http://dx.doi.org/10.1007/s13201-014-0163-0

[8] Black, J., Wagner, J., Alexander, K. and Pidgeon, P. (2008) Vehicle Road Runoff-Active Steering Control for Shoulder Induced Accidents. Proceedings of the American Control Conference, Seattle, 11-13 June 2008, 3237-3244. http://dx.doi.org/10.1109/ACC.2008.4586991

[9] Glenn, D.W. (2001) Heavy Metal Distribution for Aqueous and Solid Phases in Urban Runoff, Snowmelt and Soils. A Dessertation, 7-93.

[10] Burton, G.A. and Pitt, R.E. (2002) Stormwater Effects Handbook. A Tool for Watershed Managers, Scientists and Engineers. Lewis Publishers, CRC Press, Boca Raton.

[11] Ofosu, F.G., Hopke, P.K., Aboh, I.J.K. and Bamford, S.A. (2012) Characterization of Fine Particulate Sources at Ashaiman in Greater Accra, Ghana. Atmospheric Pollution Research, 3, 301-310. http://dx.doi.org/10.5094/APR.2012.033

[12] Boamah, L.A. (2010) The Environmental Sanitation Policy of Ghana (2010) and Stakeholder Capacity: A Case Study of Solid Waste Management in Accra and Koforidua. Institutionen för Geovetenskaper.

[13] Arnold, C.L. and Gibbons, C.J. (1996) Impervious Surface Coverage, the Emergence of a Key Environmental Indicator. Journal of the American Planning Association, 62, 243-258. http://dx.doi.org/10.1080/01944369608975688

[14] Luo, H., Luo, L., Huang, G., Liu, P., Li, J., Hu, S., Wang, F., Xu, R. and Huang, X. (2009) Total Pollution Effect of Urban Surface Runoff. Journal of Environmental Sciences, 21, 1186-1193. http://dx.doi.org/10.1016/S1001-0742(08)62402-X

[15] New Juaben Municipal Assembly (2012) The Composite Budget of the New Juaben Municipal Assembly for the 2012 Fiscal Year.

[16] Melfah, S. (2012) Optimizing Transportation Cost of Solid Waste. A Case Study in the New Juaben Municipality.

[17] Ampaw, E.M., Akuffo, B., Larbi, S.O. and Lartey, S. (2013) Time Series Modelling of Rainfall in New Juaben Muni- 
cipality of the Eastern Region of Ghana. International Journal of Business and Social Science, 4, 116-129.

[18] Ghana Statistical Service (2014) Population and Housing Census. District Analytical Report, New Juaben Municipality.

[19] EPA (2001) Parameters of Water Quality: Interpretation and Standards. 25-116.

[20] Barrett, M.E., Zuber, R.D., Collins, E.R., Malina Jr., J.F., Charbeneau, R.J. and Ward, G. (1993) A Review and Evaluation of Literature Pertaining to the Quantity and Control of Pollution from Highway Runoff and Construction. CRWR Online Report 95-5.

[21] Kayhanian, M., Fruchtman, B.D., Gulliver, J.S., Montanaro, C., Ranieri, E. and Wuertz, S. (2012) Review of Highway Runoff Characteristics: Comparative Analysis and Universal Implications. Water Research, 46, 6609-6624. http://dx.doi.org/10.1016/j.watres.2012.07.026

[22] Winkler, M. (2005) The Characterization of Highway Runoff Water Quality. Annual Review of Microbiology, 6, 207228.

[23] Göbel, P., Dierkes, C. and Coldewey, W.G. (2007) Storm Water Runoff Concentration Matrix for Urban Areas. Journal of Contaminant Hydrology, 91, 26-42. http://dx.doi.org/10.1016/j.jconhyd.2006.08.008

[24] Klimaszewska, K., Polkowsla, Z. and Namieśnik, J. (2007) Influence of Mobile Sources on Pollution of Runoff Waters from Roads with High Traffic Intensity. Polish Journal of Environmental Studies, 16, 889-897.

[25] Calhoun, Y. (2005) Environmental Issues, Water Pollution. Yael Calhoun Series Edition, Foreword by David Seideman, 10-150.

[26] Dillon, K.S. and Chanton, J.P. (2005) Nutrient Transformations between Rainfall and Stormwater Runoff in an Urbanized Coastal Environment: Sarasota Bay, Florida. Limnology and Oceanography, 50, 62-69. http://dx.doi.org/10.4319/lo.2005.50.1.0062

[27] Thorpe, A. and Harrison, R.M. (2008) Sources and Properties of Non-Exhaust Particulate Matter from Road Traffic: A Review. Science of the Total Environment, 400, 270-282. http://dx.doi.org/10.1016/j.scitotenv.2008.06.007

[28] Herngren, L., Goonetilleke, A. and Ayoko, G.A. (2005) Understanding Heavy Metal and Suspended Solids Relationships in Urban Stormwater Using Simulated Rainfall. Journal of Environmental Management, 78, 149-158. http://dx.doi.org/10.1016/j.jenvman.2005.01.013

[29] Muthukrishnan, S. (2010) Treatment of Heavy Metals in Stormwater Runoff Using Wet Pond and Wetland Mesocosms. Proceedings of the Annual International Conference on Soils, Sediments, Water and Energy, 11, 125-145.

[30] Buragohain, M., Hassan, Y. and Prasad, H. (2013) Distribution of Trace Metals in Storm Water Runoff in the Industrial Areas of Greater Guwahati of Assam, India. Journal of Current Chemical \& Pharmaceutical Sciences, 3, 161-167.

[31] Ubuoh, E.A., Anyadike, R.N.C. and Obeta, M. (2012) Environmental Risk Assessment of Heavy Metal Concentrations in Road Runoff with Atomic Absorption Spectrophotometer (AAS), Imo State, Nigeria. Journal of Environmental Earth Sciences, 4, 62-69.

[32] Lee, G.F., Jones-lee, A., Drive, E.E.M. and Macero, E. (2004) Urban Creek and Lake Water Quality Issues as Impacted by Urban Stormwater Runoff. Report by G. Fred Lee \& Associates, El Macero, 11-53.

[33] Jaradat, Q.M. and Momani, K.A. (1999) Contamination of Roadside Soil, Plants, and Air with Heavy Metals in Jordan, a Comparative Study. Turkish Journal of Chemistry, 23, 209-220.

[34] Demirak, A., Yilmaz, F., Levent Tuna, A. and Ozdemir, N. (2006) Heavy Metals in Water, Sediment and Tissues of Leuciscus cephalus from a Stream in Southwestern Turkey. Chemosphere, 63, 1451-1458. http://dx.doi.org/10.1016/j.chemosphere.2005.09.033

[35] Gardiner, L. and Armstrong, B. (2007) Identifying Sensitive Receiving Environments as Risk from Road Runoff. 2nd Edition, MWH New Zealand Ltd., Wellington.

[36] Hassan, Y., Chakrabarty, S. and Sarma, H.P. (2013) Contribution of Pollution Load of Storm Water Runoff in Shillong City. Archives of Environmental Contamination and Toxicology, 5, 38-44. 